\title{
Hava Kalitesi ve Meteoroloji: Korelasyon, Trend ve Epizot Analizleri
}

\author{
Air Quality and Meteorology: Analysis of Correlations, Trends and Episodes
}

\author{
Atilla MUTLU* \\ Balıkesir Üniversitesi, Mühendislik Fakültesi, Çevre Mühendisliği Bölümü, 10145, Balıkesir \\ • Geliş tarihi / Received: 13.05.2019 • Düzeltilerek geliş tarihi / Received in revised form: 17.07.2019 • Kabul tarihi / Accepted: 04.08.2019
}

\begin{abstract}
$\ddot{O} z$
Bu çalışmada, Güney Marmara bölgesinde bulunan Balıkesir şehir merkezine ait uzun yıllık hava kirleticilerinin yerel meteorolojik koşullar etkisinde değişimleri, trendleri ve epizotları incelenmiş̧ir. Son beş yılı kapsayan dönemde, saatlik ölçülen $\mathrm{PM}_{10}$ ve $\mathrm{SO}_{2}$ seviyeleri ve saatlik sıcaklık (t), rüzgar hızı (ws), nem (rh) ve basınç (p) verileri analiz edilmiştir. Uzun yıllık ortalamalar göz önüne alındığında, şehir merkezinde ölçülen $\mathrm{PM}_{10}$ konsantrasyonlarının ortalama değeri $47.33 \mu \mathrm{g} / \mathrm{m}^{3}$ ve $\mathrm{SO}_{2}$ konsantrasyonlarının ortalaması ise $7.75 \mu \mathrm{g} / \mathrm{m}^{3}$ olarak tespit edilmiştir. Pearson ve Kendall's Tau korelasyon analizi sonuçlarına göre, $\mathrm{PM}_{10}$ seviyelerinin değişimlerinde rüzgar hızı (ws) ve sıcaklık (t) parametrelerinin ters yönlü etkili olduğu, $\mathrm{SO}_{2}$ seviyelerinin değişimlerinde en etkili parametrenin yine ters yönde sıcaklık (t) parametresi olduğu belirlenmiştir. Hava kirleticilerinin meteorolojik parametrelerin değişimlerine göre tahmin edilebilmesi için bir regresyon modeli oluşturmuştur. Tüm meteorolojik parametrelerin modele dahil edilmesi halinde, $\mathrm{PM}_{10}$ seviyelerindeki değişimin ancak \%16 oranında, benzer şekilde $\mathrm{SO}_{2}$ seviye tahminleri ancak \%24 oranında açıklanabilmektedir. TheilSen trend analiz sonuçlarına göre, uzun yıllık dönemde $\mathrm{PM}_{10}$ ve $\mathrm{SO}_{2}$ seviyelerinin artış eğilimi gösterdiği tespit edilmiştir. Kirlilik takvimlerine göre, $\mathrm{PM}_{10}$ ve $\mathrm{SO}_{2}$ seviyeleri için epizot günleri belirlenmiştir. Epizot gününe ait olağandışı durumların araştırılması sonucunda, il merkezinde en yüksek $\mathrm{PM}_{10}$ konsantrasyonun ölçüldüğü epizot gününde Kuzey Afrika'dan kıtasal toz taşınımından gelen çöl tozlarının etkili olduğu sonucuna varılmıştır. $\mathrm{SO}_{2}$ epizot günü için, Bulgaristan'ın ülkemiz sınırına yakın olan güney doğu bölgesinde bulunan termik santrallerden yapılan salınımların bölgesel kirletici taşınımlarında etkili olduğu ve ayrıca lokal olarak Balıkesir şehir merkezinde özellikle Aralık aylarında görülen şiddetli enverziyon oluşumlarının etkili olabileceği düşünülmektedir.
\end{abstract}

Anahtar kelimeler: Balıkesir, Kendall's Tau, Pearson, $\mathrm{PM}_{10}, \mathrm{SO}_{2}$, Theil-Sen, Trend analizi

\begin{abstract}
In this study, changes, trends and episodes of long-term air pollutants under local meteorological conditions were examined at Balikesir's downtown in South Marmara region. In the last five years period, hourly measured PM ${ }_{10}$ and $\mathrm{SO}_{2}$ levels and hourly temperature ( $t$ ), wind speed (ws), humidity $(r h)$ and pressure $(p)$ data were analyzed. Considering the long-term averages, the mean value of $P M_{10}$ concentrations measured in the downtown was $47.33 \mu \mathrm{g} / \mathrm{m} 3$ and the mean of the $\mathrm{SO}_{2}$ concentrations was $7.75 \mu \mathrm{g} / \mathrm{m} 3$. According to the results of Pearson and Kendall Tau's correlation analysis, wind speed (ws) and temperature ( $t$ ) parameters were found to be inversely effective in the changes of $P M_{10}$ levels, while the most effective parameter was the inverse temperature $(t)$ parameter in the changes of $\mathrm{SO}_{2}$ levels. A regression model was used to estimate air pollutants based on the changes of the overall meteorological parameters. If all meteorological parameters are included in the model, only $16 \%$ of the $P M_{10}$ levels can just be explained, and the $\mathrm{SO}_{2}$ level estimates can only be explained by $24 \%$. According to Theil-Sen trend analysis, $\mathrm{PM}_{10}$ and $\mathrm{SO}_{2}$ levels were in an increasing trend. According to pollution calendars, the episode days for $\mathrm{PM}_{10}$ and $\mathrm{SO}_{2}$ levels were determined for the study. As a result of investigating the unusual conditions of the episode day, it was concluded that desert dusts coming from the continental dust transport from North Africa were effective on the day of the episode where the highest $\mathrm{PM}_{10}$ concentration was measured in the downtown area. For $\mathrm{SO}_{2}$ episode day, it was determined that the releases from the coal-powered energy plants in the south-eastern region near Bulgaria's border with our country might be effective in the transport of regional $\mathrm{SO}_{2}$ pollutants. In addition, it was thought that the formation of temperature inversions seen in Ballkesir's downtown especially in the months of December could be effective for the highest $\mathrm{SO}_{2}$ levels.
\end{abstract}

Keywords: Ballkesir, Kendall's Tau, Pearson, $\mathrm{PM}_{10}, \mathrm{SO}_{2}$, Theil-Sen, Trend analysis

\footnotetext{
*Atilla MUTLU; amutlu@ balikesir.edu.tr; Tel: (266) 61211 94; orcid.org/0000-0002-0777-0863
} 


\section{Giriş}

Dünya Sağlık Örgütü (WHO) 2006 y1lında hava kalitesi ile ilgili yayınlamış olduğu risk değerlendirme raporunun giriş cümlesinde "temiz hava insan sağlığ ve refahı için en temel gereksinimdir" vurgusunu yaparak günümüzde temiz havanın insan ve ekosistemi oluşturan canlılar için önemini bir kez daha ortaya koymuştur (WHO,2006). Hava kirliliği günümüzde halen halk sağlığını tehdit eden en önemli çevresel risk etmenlerinin başında yer almaktadır (WHO, 2016).

Global olarak, başlıca antropojenik hava kirleticiler kent merkezlerinde yoğunlaşmıştır. Trafik, endüstri ve isınma sistemleri kentsel hava kirliliğinin başlıca kaynaklarıdır. Meteoroloji, topografik yap1 ve kent yerleşimleri hava kirleticilerinin dispersiyon, depolanma ve kimyasal dönüşüm süreçlerine etki eden önemli faktörlerdir. Çeşitli hava kirleticilerinin çevreye ve insan sağlığına olumsuz etkileri bilinmektedir. Her bir hava kirleticinin etki süresi, konsantrasyonu ve diğer karakteristiklerine bağlı olarak insan sağlığı üzerinde etkileri olmaktadır. İnsanlar üzerindeki klinik çalışmalarda ozon $\left(\mathrm{O}_{3}\right)$, kükürtdioksit $\left(\mathrm{SO}_{2}\right)$, partiküler madde $(\mathrm{PM})$, azot oksitler $\left(\mathrm{NO}_{\mathrm{x}}\right)$ gibi kirleticilerin ve polen gibi biyojenik antijenlerin solunum yolu hastalıklarını arttırdığı rapor edilmiştir (Helander vd., 1997; Monn vd., 1999; Moshammer ve Neuberger, 2003; Martonen ve Schroeter, 2003; Borge vd., 2014). Pek çok epidemiolojik çalışmada özellikle astım gibi kronik solunum yolu hastalığına çevresel hava kirliliğinin olumsuz ektisi olduğu kabul edilmektedir (Alberini ve Krupnick, 1998; Williams vd., 2000). Havada bulunan partikül maddelerin (PM) insanlar üzerinde özellikle üst ve alt solunum yolları rahatsızlıklarında etkili olduğu bilinen bir gerçektir (WHO, 2006; Tecer, 2009; Samoli vd., 2013; Stafoggia vd., 2013).

Benzer çalışmalar, hava kirliliği seviyesi ile akciğer fonksiyonlarında düşüş, solonum yolu semptomlarında artış ve ölüm vakalarında artış arasında bir ilişkinin olduğunu göstermektedir (Wordley vd., 1997; Timonen vd., 2002). Yetişkin ve çocuklarda, solunum yolu şikayetleri veya astımda şiddetlenme sebebiyle hastaneye yatışlarda ve acil servislere başvurulardaki artışla hava kirliliği arasında ilişki olduğu bulunmuştur (Gomzi, 1999; Wong vd., 2000; Brunekreef ve Holgate, 2002).

Hava kirliliği kontrolü, insanlığın çevreye dolayısıyla atmosfere olan olumsuz etkilerinin azaltılmasına veya en azından kontrol edilmesine karş1 yapılmakta olan teknik (mühendislik) ve sosyal (eğitim) içerikli mücadelenin canlı bir örneğidir. $\mathrm{Bu}$ mücadelede dikkat çeken bazı kontrolsüz tekrarlanan zararlı, toksik maddelerin atmosfere salınımları, geçmişteki dönemlerde karşımıza 'Epizot' denilen kirlilik faciaları olarak adlandırılan trajik olaylara yol açmıştır. Bu trajedilerden bazılar1; Bhopal gaz facias1, Meksika'daki Mexico City olay1; 1953, 1963 ve 1966 yıllarında yaşanan New York kenti epizotları ve 1950 'li ve 1960 'lı yıllarda yaşanan Meuse Valley ve Londra Şehrini mahfeden duman epizotları örnek verilebilir (Wang vd., 2004; Visscher, 2014).

Hava kirliliği, insan ve diğer canlılarla birlikte aynı zamanda yapılara zarar veren maddelerin atmosferde kalma sürelerinin (zaman) ve atmosferdeki miktarlarını (konsantrasyon) çevreye olan olumsuz etkileri olarak tanımlanabilir. Kirleticiler doğal kaynaklı veya insan kaynaklı olabilirler. Doğal kaynaklı kirleticiler, insan kaynakl1 (antropojenik) kirleticilere oranla daha büyük konsantrasyonlarda havaya karışmalarına karşın sürekli değildirler (akut etki). İnsan kaynaklı kirleticiler ise, yüksek veya düşük konsantrasyonlarda fakat süreklidirler (kronik etki). Bu durumda, atmosferde bulunan kirletici yükler göz önüne alındığında, atmosferin zamanla doğal kaynaklı kirleticileri zaman içerisinde kontrol edebildiği fakat antropojenik kirletici konsantrasyonlarını ise kendi iç mekanizmasında yeterince kontrol edemediği görülmektedir.

$\mathrm{Bu}$ çalışmada, Güney Marmara bölgesinde bulunan Balıkesir iline ait uzun yıllık hava kirleticilerinin $\left(\mathrm{PM}_{10}\right.$ ve $\left.\mathrm{SO}_{2}\right)$ yine ayn zaman dilimine ait yerel meteorolojik koşullar altında değişimleri, olası trendleri ve epizotları incelenmiştir.

\section{Materyal ve Metot}

\section{1. Çalışma Alanı}

Balıkesir ili ülkemizin kuzey batı bölümünde ve Marmara Denizin güney kısmında, Güney Marmara, kalan bölgede bulunmaktadır. Balıkesir orta ölçekli bir şehirdir. Balıkesir nüfusu yaklaşık 1.2 milyon olup, nüfusun yaklaşı $1 / 3$ 'ü şehir merkezinde yaşamaktadır (URL-1, 2017). Balıkesir şehri ülkenin belli başlı et ve süt ürünleri üretim merkezi olarak da bilinmektedir. Ayrıca şehrin Organize Sanayi Bölgesinde ve diğer kısımlarında elyaf üretim tesisi, çimento fabrikası, 
ağaç işleme entegre tesisi, kağıt fabrikası, sofralık yağ üretim tesisi ve muhtelif ölçeklerde süt işleme tesisleri kurulmuş veya kurulma aşamasındadır.

Balıkesir şehrinin hem Marmara Denizinde ve hem de Ege Denizinde kıyıları mevcuttur. Şehrin karakteristik iklim özellikleri, kıyı bölgelerinde daha çok Akdeniz iklimi hüküm sürerken, iç kesimlerde ise Kara iklimi özellikleri görülmektedir. Balıkesir ilinde karakteristik olarak dört mevsim görülmektedir. Kıyı kesimlerinde kışlar 1 lık ve yağışlı geçerken, şehir merkezinin de yer aldığ 1 iç kesimlerde kışlar daha soğuk ve yağışlı geçmektedir (Koçman, 1993; Tağıll, 2007). Ayrıca şehrin kendine has topoğrafik şekli itibariyle kısmen kuzey, kuzey-batı ve güney-batı kısımlarında dağlık yükseltilerin eteklerinde kurulu olması nedeniyle çanak şeklinde olup, şehir merkezinin bulunduğu bölgede kuzeyli yönlerde oluşan doğal koridorlar üzerinden hakim rüzgar yönlerinin oluştuğu gözlenmektedir. Ayrıca, şehir merkezinin de bulunduğu iç kesimlerde, özellikle kış aylarında sıcaklık ve basınç farklılarından dolayı atmosferik inversiyon ve yoğun sis oluşumları nedeniyle kent merkezinde hava kirliliği epizotları görülmektedir (Tecer, 2013; Mutlu, 2018; Mutlu, 2019).

Şehir merkezine ait hava kalitesi değişimlerinin incelendiği bu çalışmada, şehir merkezinde İl Çevre Müdürlüğü sorumluğunda olan bir adet konvansiyonel aktif Hava Kalitesi İzleme İstasyonu (HKİi) bulunmaktadır. $\mathrm{Bu}$ istasyonun ilk yeri daha çok konut ve yaşam bölgesi olarak tabir edilen Bahçelievler Mahallesinde konumlandırılırken, sonrasında yeni bir konum olarak şehrin merkezinde Toplu Taşıma Merkezi olarak tanımlanan bölgeye taşınmıştır. Eski ve yeni HKİ konumları ve şehrin yerleşkesi Google Earth Digital Image ortamında Şekil 1'de sunulmuştur.

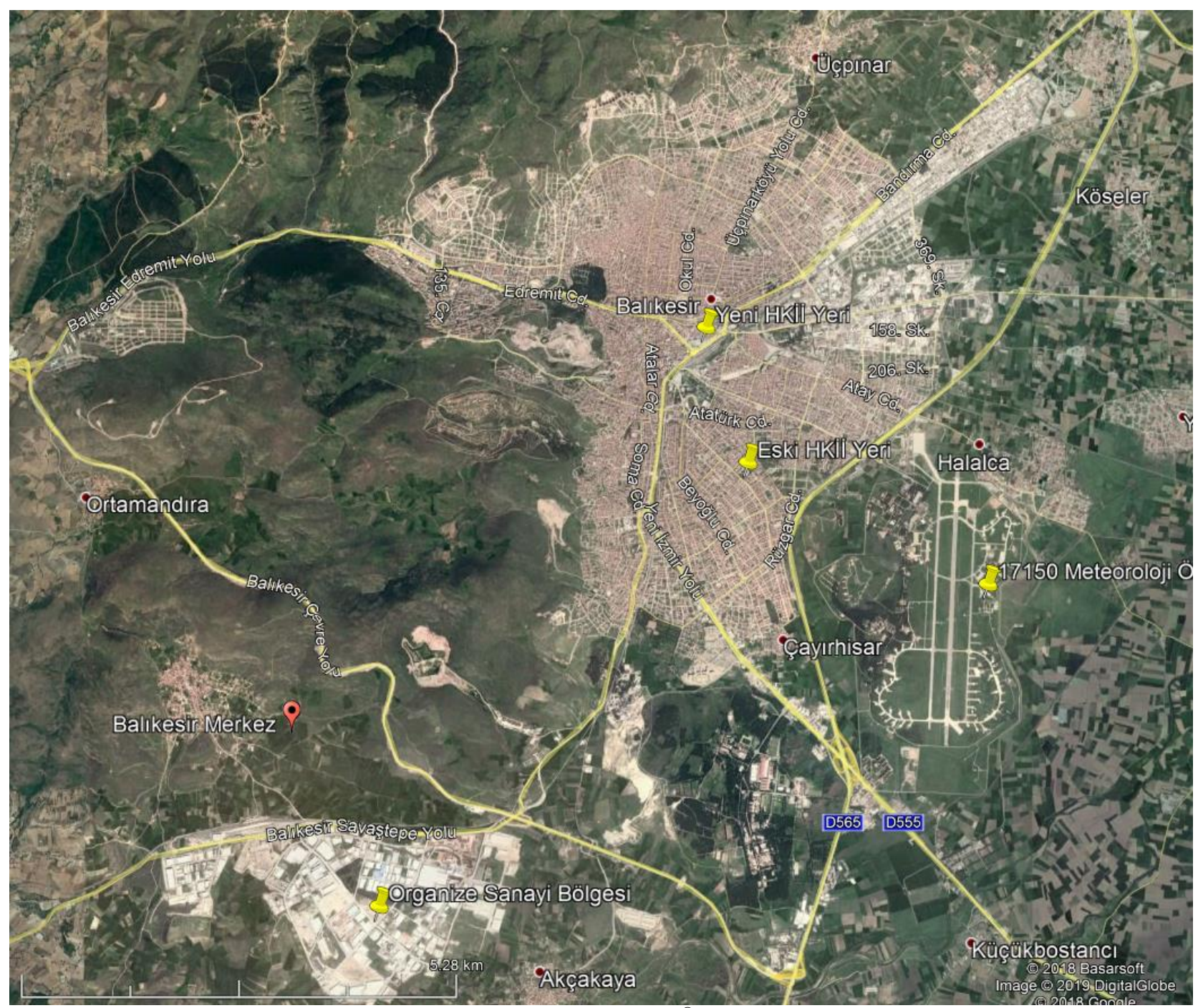

Şekil 1. Balıkesir şehir merkezi görseli. (Google Earth Image ${ }^{\mathfrak{C}}$ 2019) 


\section{1. Çalışmada Kullanılan Veriler}

Çalışmada, başlıca hava kalitesi ve bölgesel meteorolojik veri setleri olmak üzere iki türlü veri tabanından yararlanılmıştır. $\mathrm{Bu}$ farklı veri tabanları aynı zaman dilimi aralığ ölçülen ve kaydedilen veriler olup son 5 ylllık bir süreyi kapsamaktadır. Çalışma bütününde ise her bir değişken için yaklaşık 43,800 veri üzerinde çalışılmıştır.

Son beş y1lı kapsayan hava kalitesi verileri şehir merkezinde bulunan hava kalitesi izleme istasyonunun (HKIII) eski ve yeni lokasyonlarından ölçülen, saatlik $\mathrm{PM}_{10}$ ve $\mathrm{SO}_{2}$ kirleticilerini içerirken, meteorolojik veriler ise bölgede bulunan hava üssündeki meteoroloji gözlem istasyonundan (\#17150) yine saatlik olmak üzere sıcaklık (t), rüzgar hızı (ws), nem (rh) ve basınç (p) verilerini kapsamaktadır. Hem hava kalitesi ölçüm istasyonlarının yerleri, hem de meteoroloji istasyonun yerleri Şekil 1'de sunulmuştur.

Hava kalitesi ve meteorolojik veriler, istatistisel analizler için SPSS ve $\mathrm{R}$ ortamlarında değerlendirilmiş olup, elde edilen sonuçlar bir sonraki bölümde detaylı olarak açıklanmıştır.

\section{Veri Analizinde Uygulanan Yöntemler}

Yoğun nüfusu olan şehirlerde hava kalitesinin artırılabilmesi için öncelikle kirletici parametrelerin türü, miktarı ve kirletme süresi belirlenmelidir. Yani bölgenin emisyon envanteri oluşturulmalıdır. Hava kalitesinin artırılması için uygulanacak stratejinin belirlenmesinde düzenli olarak temsili ölçümlerin yapılması ve bu ölçüm sonuçlarının o bölgeye ait temsili meteorolojik koşullara göre yorumlanarak hava kalitesi trendlerinin ve epizotlarının oluşturulması gerekmektedir.

$\mathrm{Bu}$ çalışma kapsamında, şehir merkezine ait hava kalitesinin, uzun yıllık meteorolojik oluşumlar karşısında nasıl değişim gösterdiği incelemek için farklı amaçlarda bir dizi istatistiksel yöntemler kullanılmıştır.

İlk aşamada, geniş veri setini oluşturan hava kirleticileri $\left(\mathrm{PM}_{10}\right.$ ve $\left.\mathrm{SO}_{2}\right)$ ve meteorolojik parametrelerine (sıcaklık-t, rüzgar hızı-ws, nem-rh ve basınç-p) ait genel tanımlayıcı istatistiksel parametreler (ortalamalar, \%95 önem seviyesinde ortalama için güven aralıkları, min/max değerler) hesaplanmıştır. Ölçülen hava kirleticilerinin mevsimsel olarak nasıl değişim gösterdiği önemli bir konudur. $\mathrm{Bu}$ değişimler hava kalitesi analizlerinin yapıldığı o bölgedeki karakteristik özelliklerin anlaşılması bakımından önem arz eder. $\mathrm{Bu}$ nedenle hava kirleticilerine ait varyans analizi testleri (ANOVA) yapilarak kirleticileri ait mevsimsel değişimler arasında fark olup olmadığı incelenmiştir.

Ölçülen her bir saatlik değişkenin birbirleriyle olan istatistiksel bağıntılarının incelendiği ikili (bivariate) korelasyon analizleri (Pearson Correlation Analysis ve Kendall's Tau Analysis) yapılmıştır.

Veri setlerine ait birbirleriyle var olabilecek etkileşimlerin incelendiği korelasyon analizinden sonra, meteorolojik parametrelerin (sıcaklık-T, rüzgar hızı-WS, nem-RH ve basınç-P) değişimlerinde her bir hava kirleticisinin $\left(\mathrm{PM}_{10} \mathrm{ve}\right.$ $\mathrm{SO}_{2}$ ) değişimini ifade eden çoklu regresyon analizleri yapılarak, ölçülen bir dış ortam hava kirletici konsantrasyonuna ait uzun y1llik değişimlerinde, $\mathrm{o}$ kirleticinin var olduğu bölgedeki meteorolojik parametrelerin nasıl etkili olduğu sorusuna oluşturulan çoklu regresyon modelleri ile cevap verilmeye çalış1lmıştır.

Veri setlerine ait regresyon analizlerinden elde edilen sonuçlar 1şı̆̆ında hava kalitesi çalışmalarında sıklıkla kullanılan önemli trend analizlerinden birisi olan Theil-Sen korelasyon analizlerini içeren parametrik olmayan korelasyon analizleri yapilarak hava kirleticilerine ait uzun y1llık değişimlerini gösteren tren analizi yapılmıştır (Tian ve Fernandez, 1999; Elbir vd., 2000; Yolsal, 2016).

Ayrıca R ortamında geliştirilen algoritma (Carslaw ve Ropkins, 2012; Carslaw, 2015) ile dış ortam $\mathrm{PM}_{10}$ ve $\mathrm{SO}_{2}$ kirleticilerinin günlük değişimleri 2014-2018 yıllarına ait takvimlerde gösterilmiş olup, hem yıl bütünündeki değişimler hem de yasal sınır değerlerini geçen günler için epizot günleri tespit edilmiş ve bu epizot günlerine ait yüksek kirletici seviyelerinin nedenleri incelenmiştir.

\section{Bulgular ve Tartışma}

\subsection{Hava Kirleticilerine ve Meteorolojik Verilere Ait Genel İstatistikler}

Çalışmada elde edilen geniş veri setini oluşturan hava kirleticileri $\left(\mathrm{PM}_{10}\right.$ ve $\left.\mathrm{SO}_{2}\right)$ ve meteorolojik parametreler (sıcaklık, rüzgar hızı, nem ve basınç) ait genel tanımlayıc1 istatiksel parametreleri içeren, ortalamalar, \%95 önem seviyesinde ortalama için güven aralıkları, $\min / \max$ değerler Tablo 1'de sunulmuştur. 
Tablo 1. Hava Kirleticilerine ve Meteorolojik Parametrelere Ait Genel Tanımlayıcı İstatistikler

\begin{tabular}{|c|c|c|c|c|c|c|c|}
\hline \multirow{2}{*}{\multicolumn{2}{|c|}{$\begin{array}{l}\text { İstatiksel Tanımlayıcı } \\
\text { Parametreler }\end{array}$}} & \multicolumn{2}{|c|}{ Hava Kalitesi Parametreleri } & \multicolumn{4}{|c|}{ Meteorolojik Parametreler } \\
\hline & & $\mathrm{PM}_{10}$ & $\mathrm{SO}_{2}$ & $\mathrm{t}\left({ }^{\circ} \mathrm{C}\right)$ & ws (m/sn) & $\operatorname{rh}(\%)$ & $\mathrm{p}$ (mbar) \\
\hline \multicolumn{2}{|c|}{ Ortalama } & 47.33 & 7.75 & 16.2 & 1.83 & 66.35 & 977.39 \\
\hline Güven & Alt limit & 46.95 & 7.65 & 16.1 & 1.81 & 66.33 & 976.96 \\
\hline Aralığg $1 *$ & Üst limit & 47.71 & 7.85 & 16.3 & 1.84 & 66.37 & 977.83 \\
\hline Değişim & Minimum & 1 & 1 & -14.1 & 0.24 & 58.5 & 815.62 \\
\hline Aralığ1 & Maksimum & 576.3 & 146.9 & 41.6 & 7.3 & 74.2 & 1052.63 \\
\hline \multicolumn{2}{|l|}{$\mathrm{N}$} & 43824 & 43824 & 43824 & 43824 & 43824 & 43824 \\
\hline
\end{tabular}

Çalışmada, daha önceki bölümde belirtildiği üzere her bir parametre için saatlik ölçüm değeri alınmış ve son beş yılı kapsayan dönemi temsil etmesi amacıyla her bir ölçülen parametre için toplam 43824 adet veri yapılan analizlere dahil edilmiştir. Uzun yıllık ortalamalar göz önüne alındığında, şehir merkezinde ölçülen $\mathrm{PM}_{10}$ konsantrasyonlarının ortalama değeri $47.33 \mu \mathrm{g} / \mathrm{m}^{3}$ ve istatistiksel olarak \%95 önem düzeyinde $\mathrm{PM}_{10}$ ortalamasinın 46.95 ile $47.71 \mu \mathrm{g} / \mathrm{m}^{3}$ arasinda olduğu tahmin edilmektedir. En yüksek 24 saatlik $\mathrm{PM}_{10}$ seviyesi $576.3 \mu \mathrm{g} / \mathrm{m}^{3}$ olarak 1. Şubat.2015 günü saat 19 sularında ölçülmüştür. Ölçülen günlük maksimum değer hava kalitesi yasal sınırından yaklaşık 7 kat daha fazladır. (Hava Kalitesi Değerlendirme ve Yönetimi Yönetmeliği, EK1-A geçiş dönemi kademeli azaltım olarak, 2015 yılı $\mathrm{PM}_{10}$ için 24 saatlik limit değer, 90 $\mu \mathrm{g} / \mathrm{m}^{3}$ ) (HKDYY, 2008).

Yine aynı şekilde, şehir içinde ölçülen uzun yıllık $\mathrm{SO}_{2}$ konsantrasyonlarının ortalaması ise 7.75 $\mu \mathrm{g} / \mathrm{m}^{3}$ olarak hesaplanmış ve istatistiksel olarak $\% 95$ önem düzeyinde $\mathrm{SO}_{2}$ ortalamasının 7.65 ile $7.85 \mu \mathrm{g} / \mathrm{m}^{3}$ arasında olduğu tahmin edilmektedir. Çalışma periyodu kapsamında, en yüksek $\mathrm{SO}_{2}$ konsantrasyonu $146.9 \mu \mathrm{g} / \mathrm{m}^{3}$ olarak 8.Aralık.2018 saat 21 sularında ölçülmüştür. Ölçülen maksimum günlük $\mathrm{SO}_{2}$ değeri izin verilen yasal sınırların altında olduğu belirlenmiştir. (Hava Kalitesi Değerlendirme ve Yönetimi Yönetmeliği, EK1-A geçiş dönemi kademeli azaltım olarak, 2018 yılı $\mathrm{SO}_{2}$ için 24 saatlik limit değer ilgili, $380 \mu \mathrm{g} / \mathrm{m}^{3}$ ) (HKDYY, 2008).

Hava kirleticilerinin en yüksek $\mathrm{PM}_{10}$ seviyesi beklenildiği gibi kış aylarında ve gün sonlarına doğru görülmüş olup, şehir merkezinde akşam saatlerinde oluşan yoğun eve dönüşün oluşturduğu yoğun trafik faaliyetleri ve konut isınmalarından doğan etkiler burada açıkça görülmektedir. Benzer durum $\mathrm{SO}_{2}$ seviyesi için de geçerli olup, $\mathrm{PM}_{10}$ seviyesinden farklı olarak gece saatlerinde en yüksek değere ulaşmasında en büyük etkenin özellikle şehrin bir bölümünde halen kullanılan kömür yakmalı ısınma faaliyetlilerinin sebep olduğu düşünülmektedir.

\subsection{Hava Kirleticilerin Saatlik, Günlük ve Mevsimsel Dağılımları}

Şehir merkezlerinde oluşan belli başlı hava kirleticilerin mevsimsel değişimlerinin incelenmesi ayrıca önem arz etmektedir. Özellikle ani sıcaklık ve basınç farklılarının görüldüğü 1lıman mevsim geçişleri dönemlerinde, hava kirletici seviyelerinin olumsuz meteorolojik koşullar ile birlikte artış göstermesi yoğun olarak şehir merkezlerinde yaşayan insanlar üzerinde olumsuz sağlık etkileri oluşturmaktadır.

$\mathrm{Bu}$ nedenle bu bölümde, şehir merkezinde sürekli olarak ölçümleri yapılan $\mathrm{PM}_{10}$ ve $\mathrm{SO}_{2}$ kirleticilerine ait soğuk ve sicak mevsimsel değişimler öncelikle Şekil 2 ve Şekil 3'de verilen kirleticilere ait 5 yıllık dönem içinde aylık kirletici ortalamalarının dağılımlarını ifade eden box-plot grafiği üzerinde incelenmiştir.

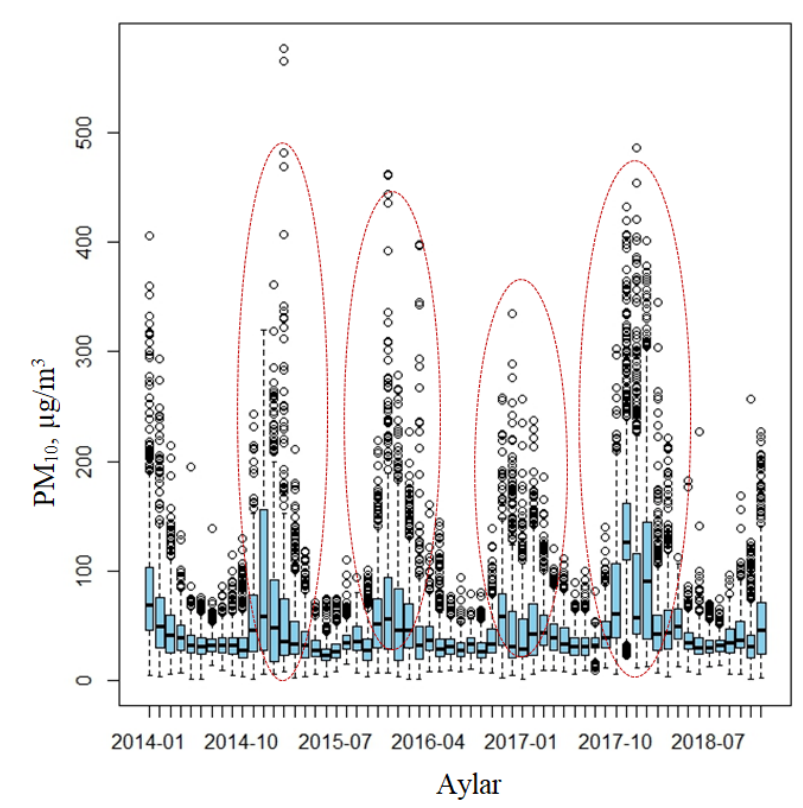

Şekil 2. Uzun döneme ait aylı $\mathrm{PM}_{10}$ değişimlerini gösteren box-plot grafiği. 
Şekil 2'de verilen box-plot grafiğinde kırmızı oval şekiller içerisinde gösterilen alanlardaki seviye farklılıklarından da anlaşılacağı üzere, $\mathbf{P M}_{10}$ kirleticisine ait aylik seviyeler sonbahar sonu ve kış aylarında artış göstermektedir. Soğuk (kış) mevsim, "Hava Kalitesi Değerlendirme ve Yönetimi Yönetmeliği" kapsamında "1.Ekim31.Mart" olarak belirtilmiştir (HKDYY, 2008). Grafiksel analizden daha fazlası olarak, $\mathrm{PM}_{10}$ seviyelerinin soğuk ve sıcak mevsimlerde değişimlerini analiz etmek için bağımsız çift örneklemeli t-testi kullanılmıştır. Test sonuçlarına göre, soğuk mevsimlerdeki $\mathrm{PM}_{10}$ seviyeleri (ortalama: $59.9 \mu \mathrm{g} / \mathrm{m}^{3}$ ), sıcak mevsimlerde oluşan $\mathrm{PM}_{10}$ seviyelerinden $\left(34.8 \mu \mathrm{g} / \mathrm{m}^{3}\right)$ matematiksel olarak fazla ve aynı zamanda aradaki bu fark $\% 95$ önem düzeyinde istatistiksel olarak da anlamlı olduğu tespit edilmiştir $\left(\mathrm{p}_{\text {value }}=0.00\right)$.

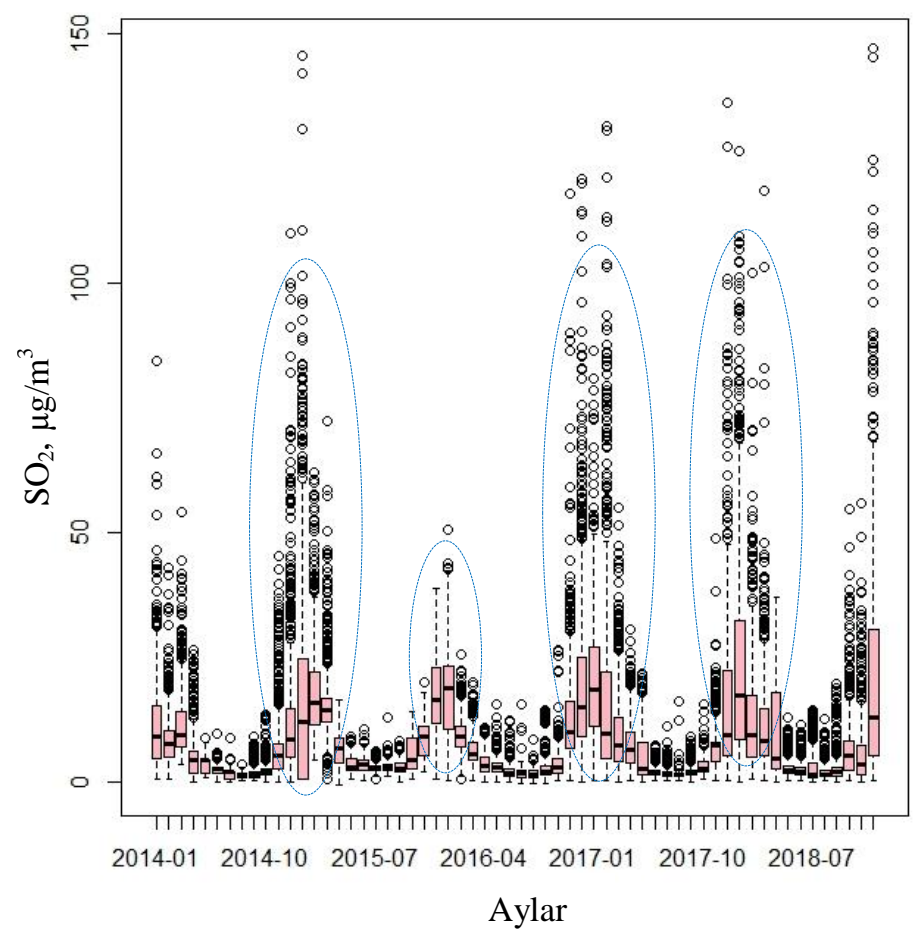

Şekil 3. Uzun döneme ait aylık $\mathrm{SO}_{2}$ değiş̧imlerini gösteren box-plot grafiği.

Benzer şekilde, Şekil 3'de verilen aylık ortalama $\mathrm{SO}_{2}$ seviyelerinin de özellikle sonbahar sonu ve kış aylarında yüksek seviyelerde olduğu tespit edilmiştir. Isınma faaliyetlerinin artış gösterdiği soğuk aylarda şehir merkezinde her ne kadar son yıllarda doğal gaz ile çalışan isınma sistemlerine geçilmiş olsa da şehir merkezinin bir bölümünün halen kömürle çalışan 1sınma sistemlerine sahip olmasından dolayı soğuk aylarda $\mathrm{SO}_{2}$ seviyelerinde artışlar görülmektedir. Mevsimler arasında fark olup, olmadığını analiz etmek için benzer şekilde, $\mathrm{SO}_{2}$ seviyelerinin soğuk ve sicak mevsimlerde değişimleri incelenmiştir. Yapılan bağımsız çift örneklemeli t-testi sonuçlarına göre, soğuk mevsimlerdeki $\mathrm{SO}_{2}$ seviyeleri (ortalama: $12.3 \mu \mathrm{g} / \mathrm{m}^{3}$ ), sicak mevsimlerde oluşan $\mathrm{SO}_{2}$ seviyelerinden (ortalama:3.2 $\mu \mathrm{g} / \mathrm{m}^{3}$ ) daha fazla olduğu ve aradaki farkın \%95 önem düzeyinde istatistiksel olarak anlamlı olduğu tespit edilmiştir $\left(p_{\text {value }}=0.00\right)$. Hava Kalitesi Değerlendirme ve Yönetimi Yönetmeliği, EK1-A geçiş dönemi kademeli azaltım olarak, 2018 y1l $\mathrm{SO}_{2}$ için kış mevsimi limit değeri $20 \mu \mathrm{g} / \mathrm{m}^{3}$ olarak verilmiş olup il merkezinde kış mevsimlerinde oluşan $\mathrm{SO}_{2}$ seviyeleri izin verilen limit değerlerin altında olduğu tespit edilmiştir (HKDYY, 2008).

Yıllar bazında kirletici değişimleri incelendiğinde, kirletici seviyelerine ait değişimlerde y1llar arasında fark olup olmadığını belirleyebilmek için varyans analizleri (ANOVA) yapılmıştır. Yıllara ait kirletici değişimlerinin incelendiğgi ANOVA analizlerinin sonuçları Tablo 2'de sunulmuştur. 
Tablo 2. Y1llara ait $\mathrm{PM}_{10}$ ve $\mathrm{SO}_{2}$ istatistikleri

\begin{tabular}{|c|c|c|c|c|c|c|c|}
\hline & \multirow{2}{*}{ Yillar } & \multirow{2}{*}{$\mathrm{N}$} & \multirow{2}{*}{ Ortalama } & \multicolumn{2}{|c|}{ 95\% Ortalama için Güven Aralığı } & \multirow{2}{*}{ Minimum } & \multirow{2}{*}{ Maksimum } \\
\hline & & & & Alt Limit & Üst Limit & & \\
\hline \multirow{5}{*}{$\mathrm{PM}_{10}$} & 2014 & 8760 & 47.31 & 46.5 & 48.0 & 1.14 & 405.44 \\
\hline & 2015 & 8760 & 43.37 & 42.5 & 44.1 & 3.00 & 576.31 \\
\hline & 2016 & 8784 & 41.85 & 41.1 & 42.5 & 1.00 & 398.24 \\
\hline & 2017 & 8760 & 56.55 & 55.5 & 57.6 & 2.10 & 485.94 \\
\hline & 2018 & 8760 & 47.57 & 46.7 & 48.4 & 1.03 & 401.94 \\
\hline \multirow{5}{*}{$\mathrm{SO}_{2}$} & 2014 & 8760 & 5.82 & 5.6 & 5.9 & 1.01 & 109.99 \\
\hline & 2015 & 8760 & 8.76 & 8.5 & 8.9 & 1.00 & 145.54 \\
\hline & 2016 & 8784 & 7.21 & 7.0 & 7.4 & 1.00 & 120.69 \\
\hline & 2017 & 8760 & 8.01 & 7.7 & 8.2 & 1.03 & 136.14 \\
\hline & 2018 & 8760 & 8.92 & 8.6 & 9.2 & 1.00 & 146.89 \\
\hline
\end{tabular}

Geçmiş y1llara ait $\mathrm{PM}_{10}$ ve $\mathrm{SO}_{2}$ değişimlerinin analiz edildiği, 2014-2018 y1lları arasında kirletici seviyelerinin değişimlerinin nasıl olduğu, bu kirleticilerin son beş y1llık zaman diliminde hangi y1llarda en yüksek kirletici seviyelerine ulaştığ 1 veya hangi yıllarda en düşük kirletici seviyelerine sahip olduğunu analiz etmek için varyans analizi
(ANOVA) ve Post-Hoc çoklu karşlaştırma testleri uygulanmıştır.

Yapılan ANOVA testi sonucuna göre, hem $\mathrm{PM}_{10}$ ve hem de $\mathrm{SO}_{2}$ kirleticilerine ait y1llık ortalamalar birbirine eșit değildir, y1llar arsında farklılıklar vardır $\left(\mathrm{PM}_{10}\right.$ için $\mathrm{p}_{\text {value }}=0.00$ ve $\mathrm{SO}_{2}$ için $\mathrm{p}_{\text {value }}=0.00$ )

Tablo 3. Kirleticilerin yıl bazında kıyaslamalarını içeren Post-Hoc/LSD testi sonuçları

\begin{tabular}{|c|c|c|c|c|c|c|c|c|c|}
\hline Kirletici & (I) Y1l & (J) Y1l & $\begin{array}{c}\text { Ortalama Fark1 } \\
(\mathrm{I}-\mathrm{J})\end{array}$ & $\mathrm{p}_{\text {values }}$ & Kirletici & (I) Yil & (J) Y1l & $\begin{array}{c}\text { Ortalama Fark1 } \\
(\mathrm{I}-\mathrm{J})\end{array}$ & $\mathrm{p}_{\text {values }}$ \\
\hline \multirow{20}{*}{$\mathbf{P M}_{10}$} & \multirow{4}{*}{2014} & 2015 & $3.93^{*}$ & 0.00 & \multirow{20}{*}{$\mathrm{SO}_{2}$} & $\underline{2014}$ & 2015 & $-2.94^{*}$ & 0.00 \\
\hline & & 2016 & $5.45^{*}$ & 0.00 & & & 2016 & $-1.38^{*}$ & 0.00 \\
\hline & & 2017 & $-9.24^{*}$ & 0.00 & & & 2017 & $-2.19^{*}$ & 0.00 \\
\hline & & 2018 & -0.26 & 0.659 & & & 2018 & $-3.09^{*}$ & 0.00 \\
\hline & \multirow{4}{*}{2015} & 2014 & $-3.93^{*}$ & 0.00 & & 2015 & 2014 & $2.94^{*}$ & 0.00 \\
\hline & & 2016 & $1.51^{*}$ & 0.012 & & & 2016 & $1.55^{*}$ & 0.00 \\
\hline & & 2017 & $-13.18^{*}$ & 0.00 & & & 2017 & $0.75^{*}$ & 0.00 \\
\hline & & 2018 & $-4.20^{*}$ & 0.00 & & & 2018 & -0.15 & 0.32 \\
\hline & \multirow{4}{*}{$\underline{2016}$} & 2014 & $-5.45^{*}$ & 0.00 & & 2016 & 2014 & $1.38^{*}$ & 0.00 \\
\hline & & 2015 & $-1.51^{*}$ & 0.012 & & & 2015 & $-1.55^{*}$ & 0.00 \\
\hline & & 2017 & $-14.69^{*}$ & 0.00 & & & 2017 & $-0.80^{*}$ & 0.00 \\
\hline & & 2018 & $-5.72^{*}$ & 0.00 & & & 2018 & $-1.71^{*}$ & 0.00 \\
\hline & \multirow{4}{*}{$\underline{2017}$} & 2014 & $9.24^{*}$ & 0.00 & & 2017 & 2014 & $2.19^{*}$ & 0.00 \\
\hline & & 2015 & $13.18^{*}$ & 0.00 & & & 2015 & $-0.75^{*}$ & 0.00 \\
\hline & & 2016 & $14.69^{*}$ & 0.00 & & & 2016 & $0.80^{*}$ & 0.00 \\
\hline & & 2018 & $8.97^{*}$ & 0.00 & & & 2018 & $-0.90^{*}$ & 0.00 \\
\hline & \multirow{4}{*}{2018} & 2014 & 0.26 & 0.659 & & $\underline{2018}$ & 2014 & $3.09^{*}$ & 0.00 \\
\hline & & 2015 & $4.20^{*}$ & 0.00 & & & 2015 & 0.15 & 0.32 \\
\hline & & 2016 & $5.72^{*}$ & 0.00 & & & 2016 & $1.71^{*}$ & 0.00 \\
\hline & & 2017 & $-8.97^{*}$ & 0.00 & & & 2017 & $0.90^{*}$ & 0.00 \\
\hline
\end{tabular}

*Fark \%95 önem düzeyinde istatistiksel olarak önemlidir 
Tablo 3.'de sunulan, Post-Hoc çoklu kıyaslama testi için seçilen LSD (Least Squared Difference) yöntemine göre; $\mathrm{PM}_{10}$ seviyelerinde en yüksek yıllık ortalama 2017 yılında ölçülmüş olup, en düşük yıllık $\mathrm{PM}_{10}$ ortalamas1 ise 2016 y1lında ölçülmüştür. Yine aynı şekilde, en yüksek yıllık $\mathrm{SO}_{2}$ ortalaması 2018 yılında ve en düşük yıllık $\mathrm{SO}_{2}$ ortalaması ise 2014 yılında ölçülmüştür. Her iki hava kirleticilerinin pik yaptığı yıllar veya en düşük seviyeye ulaştığı yıllar birbirinden farklıdır.

\subsection{Hava Kirleticileri ile Meteorolojik Parametreler Arası Etkileşimler}

Bölgesel meteorolojik koşullar, hava kirleticilerinin birincil ve ikincil oluşumlarında, taşınımlarında ve birikimlerinde önemli oynamaktadırlar (Radaideh, 2017). Yapılan birçok araştırma, hava kalitesi ile meteorolojik parametreler arasında önemli bir ilişkinin olduğunu ortaya koymuşlardır. Özellikle rüzgar hızı ve yönü, sıcaklık ve oransal nemin hava kalitesi üzerinde önemli etkilere sahip olduğunu belirtmiştir. (Elminir, 2005; Beaver ve Palazoglu, 2009; Jacob ve Winner, 2009; Csavina vd., 2014; Zhang vd., 2015).

Çalışmamızda, öncelikle ele alınan iki emel hava kirleticileri olan $\mathrm{PM}_{10}$ ve $\mathrm{SO}_{2}$ seviyelerinin birbiriyle olan ilişkileri grafiksel olarak $\mathrm{R}$ ortamında (Carslaw ve Ropkins, 2012) ve (Carslaw, 2015) tarafindan geliştirilen "Openair" algoritmas1 kullanılarak incelenmiştir. Hava kirleticileri arasındaki ilişkinin değişimi ile ilgili oluşturulan grafiksel görsel Şekil 4'de sunulmuştur.

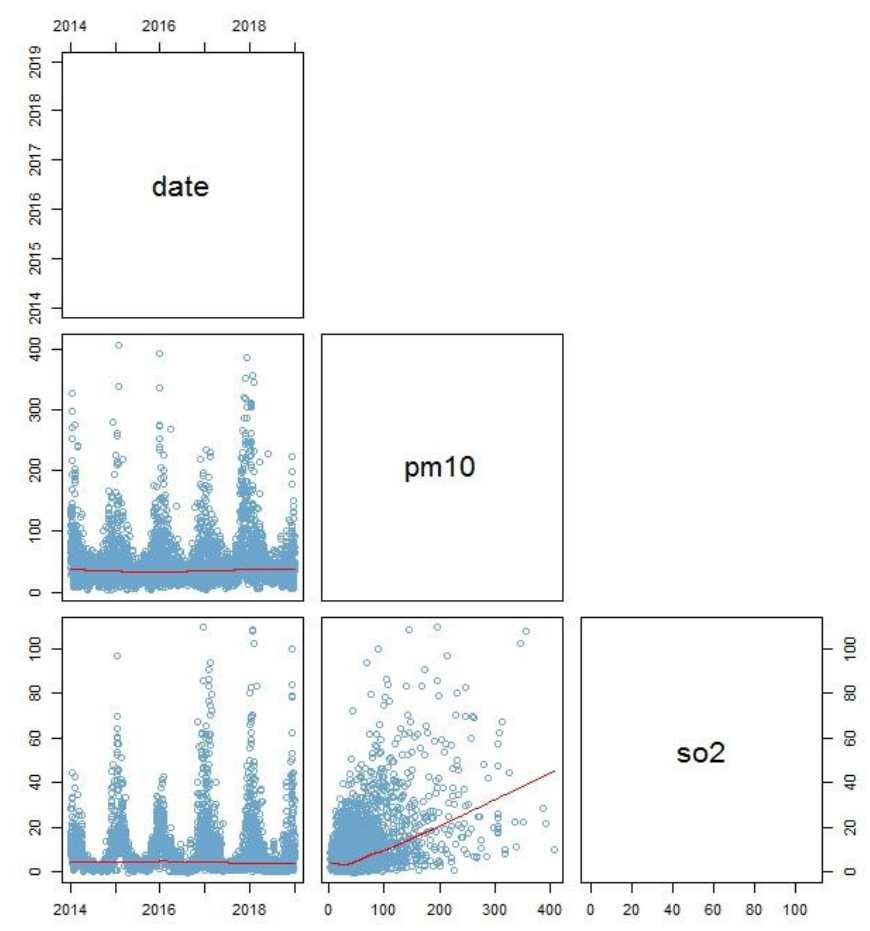

Şekil 4. $\mathrm{PM}_{10}$ ve $\mathrm{SO}_{2}$ seviyelerinin zamansal ve bire-bir değişimi

Hava kirleticilerinin birbiriyle olan etkileşimlerini incelemek amaciyla oluşturulan grafiksel görselde (Şekil 4) $\mathrm{PM}_{10}$ ve $\mathrm{SO}_{2}$ arasinda pozitif yönde güçlü bir ilişkinin olduğu görülmektedir. Bir başka ifadeyle, $\mathrm{PM}_{10}$ seviyeleri artış eğiliminde olduğu zaman bu değişimle birlikte şehir merkezinde aynı zamanda $\mathrm{SO}_{2}$ seviyelerinde de artış meydana gelmektedir. Özellikle soğuk mevsimlerde, $\mathrm{PM}_{10}$ ve $\mathrm{SO}_{2}$ konsantrasyonlarının yüksek seviyelerde olması, Balıkesir bölgesi için özellikle 1sınmadan kaynaklı salınımlarda atmosferik $\mathrm{PM}_{10}$ ve $\mathrm{SO}_{2}$ seviyelerinin birbiriyle etkileşimi açısından önemli bir sonuç ifade etmektedir.

Yine R ortamında oluşturulan her bir kirleticiye ait meteorolojik parametreler karşında değişimlerini gösteren dağılımlar Şekil 5 ve Şekil 6'da sunulmuştur. 


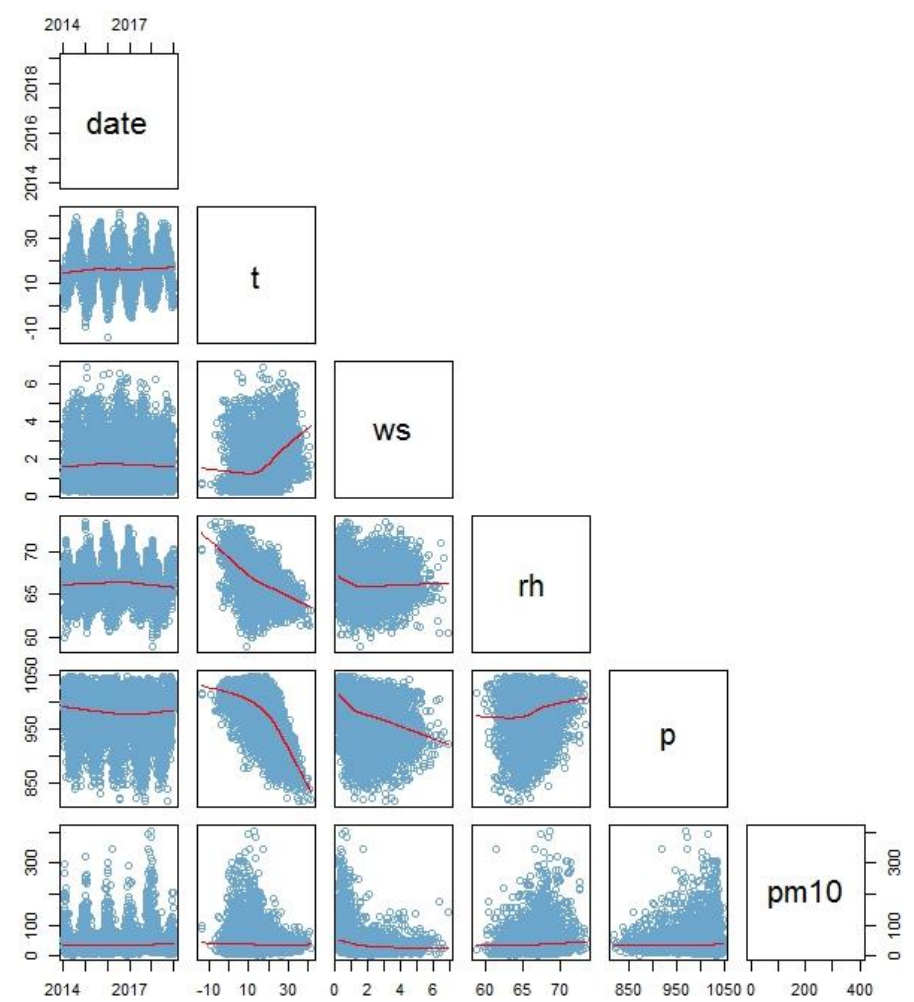

Şekil 5. $\mathrm{PM}_{10}$ seviyelerinin meteorolojik parametreler ile değişimleri

Şehir merkezine ait son beş yıllık $\mathrm{PM}_{10}$ seviyeleri ile yine aynı bölgede düzenli olarak ölçülen meterolojik parametrelerin birbirleriyle olan değişimleri Şekil 5'de sunulmuştur. $\mathrm{PM}_{10}$ seviyelerinin değişiminde etkili olan meteorolojik parametrelerden sıcaklık (t) ve rüzgar hızı (ws) ön plana çıkmaktadır. Sıcaklık ve rüzgar hızı $\mathrm{PM}_{10}$ seviyelerinin değişiminde negatif yönde etki yaptığı bu çoklu karşılaştırmalı grafiklerden anlaşılabilmektedir. Her bir meteorolojik parametrenin $\mathrm{PM}_{10}$ seviyelerindeki değişimlere olan etki derecesin daha net görebilmek için korelasyon analizlerinin yapılması gerekmektedir.
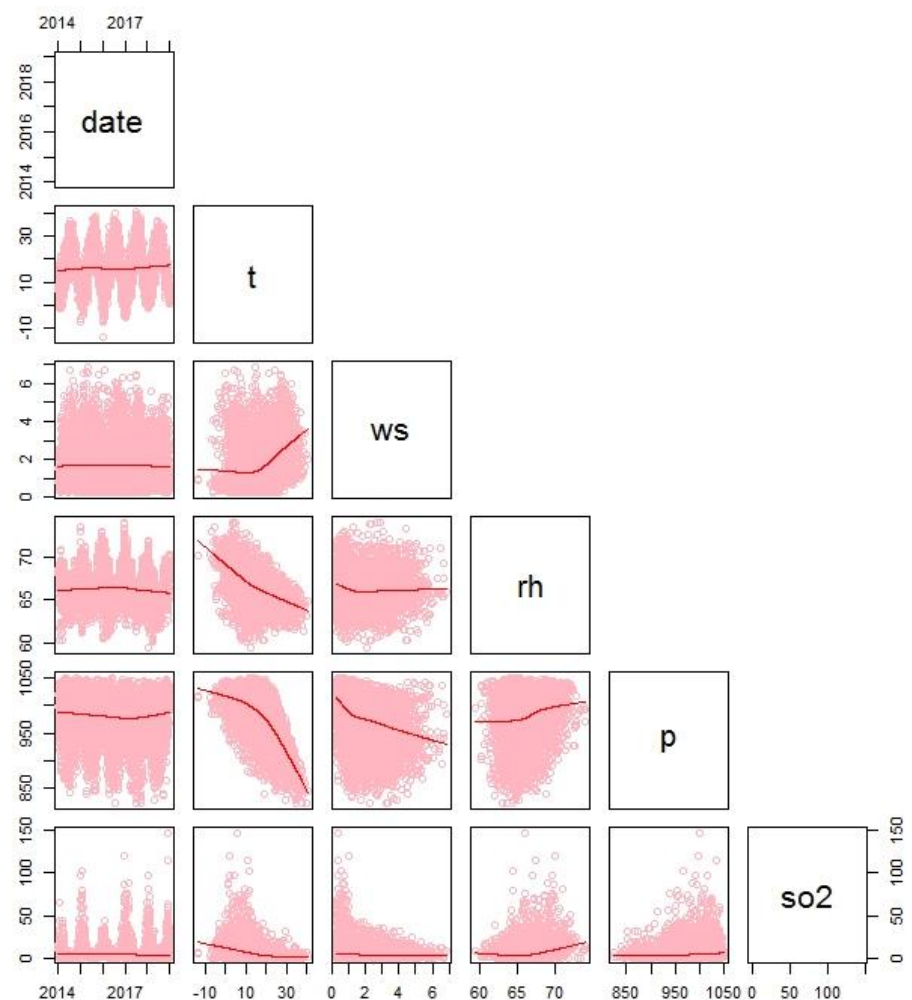

Şekil 6. $\mathrm{SO}_{2}$ seviyelerinin meteorolojik parametreler ile değişimleri 
Benzer şekilde $\mathrm{SO}_{2}$ seviyelerinin de yerel meteorolojik paramtreler ile olan değişimleri Şekil 6 'da çoklu olarak karşılaştırılmıştır. İlgili grafikte görülebileceği üzere, $\mathrm{SO}_{2}$ seviyelerinde en önemli rol oynayan meteorolojik parametrelerin sicaklik $(\mathrm{t})$ ve sonrasında nem (rh) olduğu tespit edilmiştir. $\mathrm{PM}_{10}$ seviye değişimlerinde olduğu gibi, $\mathrm{SO}_{2}$ seviyelerinin meteorolojik parametreler karşısında değişimlerinin daha net belirleyebilmek için korelasyon analizlerinin yapılması gerekmektedir. Korelasyon analizlerine ait sonuçlar bir sonraki bölümde detaylı olarak ifade edilmiştir.

\subsection{Hava Kirleticilerinin Meteorolojik Veriler Ile Modellenmesi}

$\mathrm{PM}_{10}$ ve $\mathrm{SO}_{2}$ hava kirleticilerinin değişimlerinde önemli rol oynayan meteorolojik parametrelerin, kirleticiler ile ilgili olası istatistiksel ilişkilerini incelemek amaciyla ilk olarak Pearson korelasyon analizleri yapılmıştır. Bu tür korelasyon analizleri çevresel ve hava kirliliği çalışmalarında yaygın olarak kullanılmaktadır (Çakır ve Abdullah, 2017; Y1lmaz, 2017; Topal ve Hayaloğlu, 2017; Mutlu, 2019). Korelasyon analizi sonuçları Tablo 4'de sunulmuştur.

Tablo 4. Pearson korelasyon analizi sonuçları

\begin{tabular}{ccccccc}
\hline \multicolumn{7}{c}{ Çoklu Korelasyon Matrisleri } \\
\hline PM $_{10}$ & & $\mathrm{PM}_{10}$ & $\mathrm{t}$ & $\mathrm{ws}$ & $\mathrm{rh}$ & $\mathrm{p}$ \\
& $\mathrm{PM}_{10}$ & $\mathbf{1 . 0 0 0}$ & -0.22 & -0.34 & 0.20 & 0.11 \\
Pearson Korelasyon & $\mathrm{t}$ & -0.22 & $\mathbf{1 . 0 0 0}$ & 0.28 & -0.53 & -0.66 \\
Katsay1lar1 & $\mathrm{ws}$ & -0.34 & 0.28 & $\mathbf{1 . 0 0 0}$ & -0.09 & -0.36 \\
& $\mathrm{rh}$ & 0.20 & -0.53 & -0.09 & $\mathbf{1 . 0 0 0}$ & 0.21 \\
& $\mathrm{p}$ & 0.11 & -0.66 & -0.36 & 0.21 & $\mathbf{1 . 0 0 0}$ \\
\hline $\mathrm{SO}_{2}$ & & $\mathrm{SO}_{2}$ & $\mathrm{t}$ & $\mathrm{ws}$ & $\mathrm{Rh}$ & $\mathrm{p}$ \\
& $\mathrm{SO}_{2}$ & $\mathbf{1 . 0 0 0}$ & -0.41 & -0.23 & 0.27 & 0.14 \\
Pearson Korelasyon & $\mathrm{t}$ & -0.41 & $\mathbf{1 . 0 0 0}$ & 0.28 & -0.53 & -0.66 \\
Katsay1lar1 & $\mathrm{ws}$ & -0.23 & 0.28 & $\mathbf{1 . 0 0 0}$ & -0.09 & -0.36 \\
& $\mathrm{rh}$ & 0.27 & -0.53 & -0.09 & $\mathbf{1 . 0 0 0}$ & 0.21 \\
& $\mathrm{p}$ & 0.14 & -0.66 & -0.36 & 0.21 & $\mathbf{1 . 0 0 0}$ \\
\hline
\end{tabular}

Pearson korelasyon analizi sonuçlarına göre, Balıkesir şehir merkezinde $\mathrm{PM}_{10}$ seviyelerinin değişimleri öncelikle rüzgar hızı (ws) ve sonrasinda sicaklik (t) parametreleri ile ilişkilendirilebilir. En yüksek korelasyon katsayıları rüzgar hızı ve sıcaklık olarak belirlenmiş olup, rüzgar hızı ve sıcaklık artması durumunda $\mathrm{PM}_{10}$ seviyelerinde azalma yönünde bir eğilim göze çarpmaktadır.
Benzer durum, $\mathrm{SO}_{2}$ seviyeleri incelendiğinde de görülmektedir. Şöyle ki, $\mathrm{SO}_{2}$ seviyelerinin değişimlerinde en yüksek korelasyon katsayısı yine sicaklik (t) parametresinde belirlenmiştir. Sicaklık parametresinden sonra, nem (rh) ve yine rüzgar hızı (ws) önemli rol oynamaktadır. $\mathrm{SO}_{2}$ seviyeleri sıcaklık ve rüzgar hızı artışı ile azalma eğiliminde olup, nemin artması ile artış eğilimde olmaktadir.

Tablo 5. Kendall's Tau korelasyon analizi sonuçları

\begin{tabular}{|c|c|c|c|c|c|c|c|}
\hline \multicolumn{8}{|c|}{ Çoklu Korelasyon Matrisleri } \\
\hline \multirow{8}{*}{$\begin{array}{l}\text { Kendall's Tau } \\
\text { Korelasyonu }\end{array}$} & \multirow{4}{*}{$\mathbf{P M}_{10}$} & & $\mathrm{PM}_{10}$ & $\mathrm{t}$ & WS & rh & $\mathrm{p}$ \\
\hline & & Korelasyon Katsayıları & 1.000 & $-0.08^{* *}$ & $-0.32^{* *}$ & $0.10^{* *}$ & $0.02^{* *}$ \\
\hline & & $\mathrm{p}_{\text {values }}$ & . & 0.00 & 0.00 & 0.00 & 0.00 \\
\hline & & $\mathrm{N}$ & 43824 & 43824 & 43824 & 43824 & 43824 \\
\hline & \multirow{4}{*}{$\mathrm{SO}_{2}$} & & $\mathrm{SO} 2$ & $\mathrm{t}$ & ws & rh & $\mathrm{p}$ \\
\hline & & Korelasyon Katsayıları & 1.000 & $-0.39^{* *}$ & $-0.17^{* *}$ & $0.21^{* *}$ & $0.12^{* *}$ \\
\hline & & $\mathrm{p}_{\text {values }}$ & . & 0.00 & 0.00 & 0.00 & 0.00 \\
\hline & & $\mathrm{N}$ & 43824 & 43824 & 43824 & 43824 & 43824 \\
\hline
\end{tabular}

${ }^{{ }^{* * *}}$ Fark \%95 önem düzeyinde istatistiksel olarak önemlidir

Çevresel analizlerde bağımsız ve normal dağılım gösteren geniş veri setlerinde yine çok kullanılan bir başka korelasyon analizi ise Kendall's Tau analizidir (Cerro vd., 2015; Yolsal, 2016; Sanchez de la Campa vd., 2018). Korelasyon analiz sonuçları Tablo 5 'de sunulmuş olup, $\mathrm{PM}_{10}$ 
seviyelerindeki değişimlerde rüzgar hızının (ws) en yüksek korelasyona, $\mathrm{SO}_{2}$ seviyelerinde değişimler de ise sicaklığın (t) en yüksek korelasyona sahip olduğu sonucuna varılmıştır. $\mathrm{Bu}$ sonuçla, Pearson korelasyon analizine benzer olarak, Kendall's Tau korelasyon analiz sonuçlarına göre, rüzgar hızı ile $\mathrm{PM}_{10}$ seviyelerinin değişimine ilişkin ters yönlü korelasyon ve yine sicaklık ile $\mathrm{SO}_{2}$ seviyelerinin değişimi arasında ise yine beklenildiği gibi ters yönlü korelasyon olduğu sonuçlarına varılmıştır.

Analiz kapsamında, ayrıca tüm parametrelerin mevsimlere ait korelasyonları ayrı ayrı incelenmiş olup, mevsimsel korelasyon grafikleri $\mathrm{R}$ ortamında oluşturulmuştur. İlgili mevsimsel korelasyonların sonuçlarının verildiği görsel Şekil 7'de sunulmuştur.

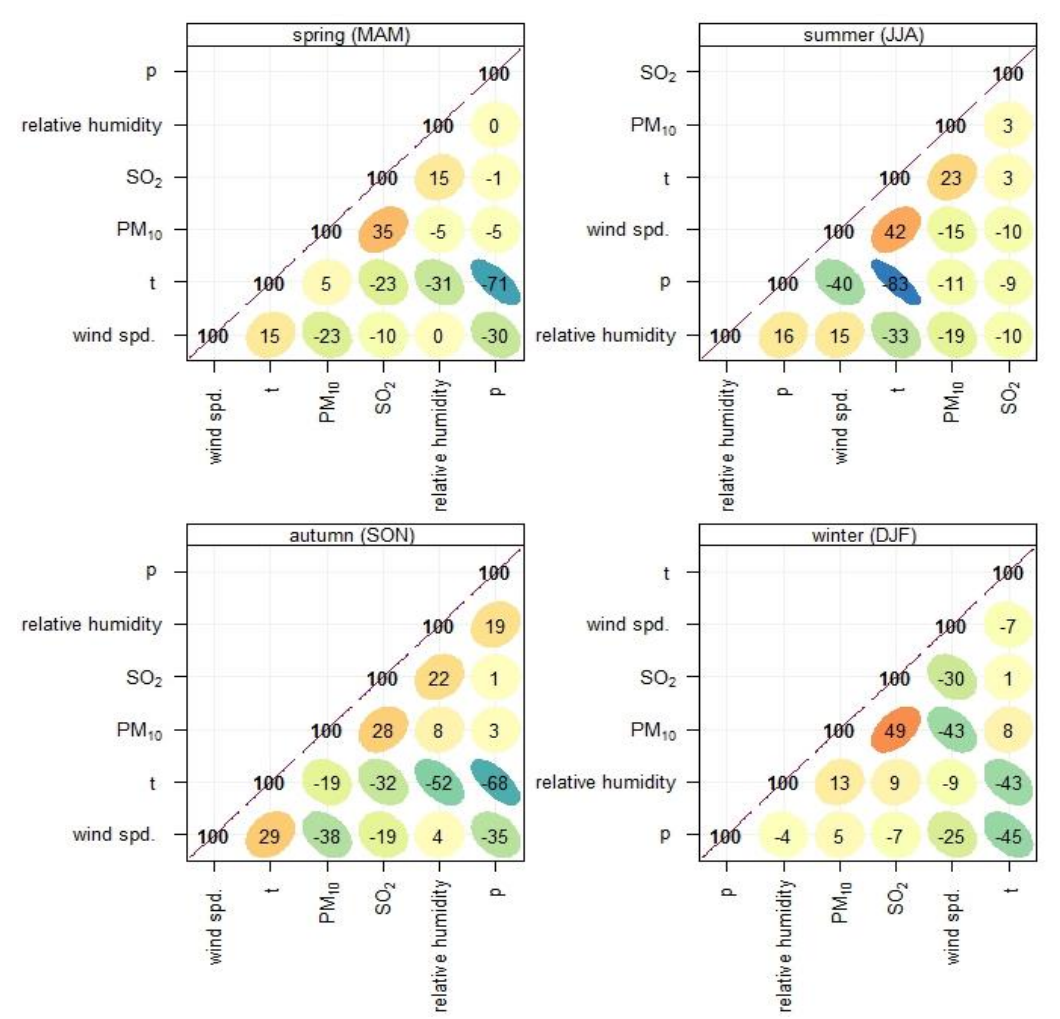

Şekil 7. Mevsimlere ait korelasyon analizi sonuçları

Hava kirleticilerinin ve meteorolojik parametrelerin mevsimsel olarak birbirleriyle nas1 etkileşim halinde olduğunu görebilmek için Şekil 7 'de verildiği üzere mevsimlere ait çoklu korelasyon grafikleri oluşturulmuştur.

Grafikten de görüleceği üzere, en yüksek korelasyon $\mathrm{PM}_{10}$ ve $\mathrm{SO}_{2}$ arasinda 0.49 olarak pozitif eğilimli olarak kış mevsiminde tespit edilmiştir. En düşük korelasyon ise 0.03 olarak yaz mevsiminde görülmüştür. Yine daha önceki korelasyon analizlerine benzer olarak, $\mathrm{PM}_{10}$ ile rüzgar hızı, ayrıca $\mathrm{SO}_{2}$ ile sicaklık arasinda özellikle 1lı mevsimlerde yani ilkbahar, sonbahar ve soğuk mevsim olan kış mevsimlerinde görülmüştür. $\mathrm{Bu}$ sonuçlar daha önce yapılan Pearson ve Kendall's Tau analizleri ile uyum sağlamaktadır.

Kirleticiler üzerinde her bir meteorolojik parametrenin ayrı ayrı korelasyonlarının incelenmesinden sonra, tüm meteorolojik parametrelerin bütün olarak etkisinde hava kirleticileri seviyelerinin deterministik olarak modellenebilmesi için hava kirleticileri ve tüm meteorolojik parametrelerden oluşan bir regresyon modeli oluşturmuştur.

Oluşturulan regresyon modelinde, $\mathrm{PM}_{10}$ ve $\mathrm{SO}_{2}$ parametreleri bağımlı değişkenler, tüm meteorolojik parametreler ise bağımsız değişkenler olarak tanımlanmıştır. Oluşturulan regresyon modelinde "stepwise" yöntemi kullanılarak, her bir bağımlı değişkeni açılklayabilmek için bağımsız değişkenler her bir adımda modele tek tek dahil edilerek, modelde gerekli olan tüm bağımsız verilerin etkisi araştırılmış ve en yüksek $R^{2}$ değerine sahip model, bağımlı değişkeni açıklayabilmede uygun model olarak seçilmiştir. $\mathrm{PM}_{10}$ seviyelerinin tahmin edilmesinde kurulan regresyon model sonuçları Tablo 6'da sunulmuştur. 
Tablo 6. $\mathrm{PM}_{10}$ parametresi için oluşturulan regresyon modeli adımları

\begin{tabular}{|c|c|c|c|c|c|c|}
\hline \multicolumn{2}{|c|}{ Model Adımları } & \multicolumn{2}{|c|}{ Model Katsayıları } & \multirow[t]{2}{*}{$\mathrm{t}$ istatistiği } & \multirow[t]{2}{*}{$\mathrm{p}_{\text {values }}$} & \multirow[t]{2}{*}{$\mathrm{R}^{2}$} \\
\hline & & $\beta$ & Std. Error & & & \\
\hline \multirow{2}{*}{1} & $\beta_{\mathrm{o}}$ & 66.290 & 0.306 & 216.806 & 0.00 & \multirow[t]{2}{*}{0.12} \\
\hline & $\beta_{1}(w s)$ & -10.374 & 0.135 & -77.026 & 0.00 & \\
\hline \multirow{3}{*}{2} & $\beta_{\mathrm{o}}$ & -155.806 & 5.693 & -27.368 & 0.00 & \multirow[t]{3}{*}{0.15} \\
\hline & $\beta_{1}(w s)$ & -9.906 & 0.133 & -74.513 & 0.00 & \\
\hline & $\beta_{2}(\mathrm{rh})$ & 3.334 & 0.085 & 39.066 & 0.00 & \\
\hline \multirow{4}{*}{3} & $\beta_{0}$ & -123.071 & 6.473 & -19.012 & 0.00 & \multirow[t]{4}{*}{0.15} \\
\hline & $\beta_{1}(w s)$ & -10.440 & 0.142 & -73.495 & 0.00 & \\
\hline & $\beta_{2}(\mathrm{rh})$ & 3.515 & 0.087 & 40.430 & 0.00 & \\
\hline & $\beta_{3}(\mathrm{p})$ & -0.045 & 0.004 & -10.579 & 0.00 & \\
\hline \multirow{5}{*}{4} & $\beta_{\mathrm{o}}$ & 36.960 & 9.847 & 3.754 & 0.00 & \multirow[t]{5}{*}{0.16} \\
\hline & $\beta_{1}(w s)$ & -10.234 & 0.142 & -72.254 & 0.00 & \\
\hline & $\beta_{2}(\mathrm{rh})$ & 2.339 & 0.102 & 22.859 & 0.00 & \\
\hline & $\beta_{3}(\mathrm{p})$ & -0.118 & 0.005 & -21.771 & 0.00 & \\
\hline & $\beta_{4}(\mathrm{t})$ & -0.687 & 0.032 & -21.483 & 0.00 & \\
\hline
\end{tabular}

$\mathrm{PM}_{10}$ hava kirleticisi için oluşturulan regresyon modeline ait adımlar Tablo 6'da gösterilmiştir. Regresyon analizi adımlarında, modele önce rüzgar hızı (ws) bağımsız değişkeni eklenmiş ve uygun $\mathrm{R}^{2}, \beta_{\mathrm{o}}$ ve $\beta_{1}$ katsayıları hesaplanarak model oluşturulmuştur. $\mathrm{Bu}$ oluşturulan ilk adım model için $\mathrm{R}^{2}$ değeri 0.12 olarak hesaplanmıştır. Bunun anlamı, oluşturulan modelde, $\mathrm{PM}_{10}$ seviyesinin tahmin etmek için sadece rüzgar hızı bağımsız değişkeni kullanılırsa, bu tek parametre olan rüzgar hızı modele dahil edilerek, $\mathrm{PM}_{10}$ seviyesini sadece $\% 12$ oranında açıklayabilir sonucuna varılmaktadır. Modele tüm bağımsız değişkenler olan meteorolojik parametreler dahil edildiğinde (4.adım) ise, $\mathrm{R}^{2}$ değeri 0.16 olarak hesaplanmış olup ayrıca sabit katsayı $\left(\beta_{\mathrm{o}}\right)$ ve her bir bağımsız değişkenlere ait katsayılar $\left(\beta_{1}, \beta_{2}, \beta_{3}\right.$ ve $\left.\beta_{4}\right)$ hesaplanmıştır. Tüm meteorolojik parametrelerin kullanılmas1 halinde, $\mathrm{PM}_{10}$ seviyesi ancak \%16 oranında tahmin edilebilir veya açıklanabilir sonucunda varılmaktadır. Benzer şekilde, $\mathrm{SO}_{2}$ seviyelerinin tahmin edilmesinde kurulan regresyon model sonuçları Tablo 7'de sunulmuştur.

Tablo 7. $\mathrm{SO}_{2}$ parametresi için oluşturulan regresyon modeli adımları

\begin{tabular}{|c|c|c|c|c|c|c|}
\hline \multicolumn{2}{|c|}{ Model Adımları } & \multicolumn{2}{|c|}{ Model Katsayıları } & \multirow[t]{2}{*}{ t istatistiği } & \multirow[t]{2}{*}{$p_{\text {values }}$} & \multirow[t]{2}{*}{$\mathrm{R}^{2}$} \\
\hline & & $\beta$ & Std. Error & & & \\
\hline \multirow[b]{2}{*}{1} & $\beta_{\mathrm{o}}$ & 15.954 & 0.097 & 165.150 & 0.00 & 0.18 \\
\hline & $\beta_{1}(\mathrm{t})$ & -0.507 & 0.005 & -96.585 & 0.00 & \\
\hline \multirow{3}{*}{2} & $\beta_{o}$ & 73.349 & 1.354 & 54.187 & 0.00 & 0.21 \\
\hline & $\beta_{1}(t)$ & -0.700 & 0.007 & -101.961 & 0.00 & \\
\hline & $\beta_{2}(\mathrm{p})$ & -0.056 & 0.001 & -42.505 & 0.00 & \\
\hline \multirow{4}{*}{3} & $\beta_{\mathrm{o}}$ & 88.258 & 1.381 & 63.908 & 0.00 & 0.23 \\
\hline & $\beta_{1}(\mathrm{t})$ & -0.683 & 0.007 & -101.019 & 0.00 & \\
\hline & $\beta_{2}(\mathrm{p})$ & -0.068 & 0.001 & -51.711 & 0.00 & \\
\hline & $\beta_{3}(\mathrm{ws})$ & -1.415 & 0.035 & -39.956 & 0.00 & \\
\hline \multirow{5}{*}{4} & $\beta_{\mathrm{o}}$ & 78.352 & 2.463 & 31.813 & 0.00 & 0.24 \\
\hline & $\beta_{1}(\mathrm{t})$ & -0.662 & 0.008 & -82.792 & 0.00 & \\
\hline & $\beta_{2}(\mathrm{p})$ & -0.067 & 0.001 & -49.597 & 0.00 & \\
\hline & $\beta_{3}(w s)$ & -1.420 & 0.035 & -40.076 & 0.00 & \\
\hline & $\mathrm{B}_{4}(\mathrm{rh})$ & 0.124 & 0.026 & 4.857 & 0.00 & \\
\hline
\end{tabular}


Daha önce oluşturulan $\mathrm{PM}_{10}$ regresyon modeline benzer olarak, bağımlı değişken olarak $\mathrm{SO}_{2}$ seviyeleri kullanılmış olup, diğer bağımsız parametreler olan meteorolojik parametreler ise tek tek modele dahil edilmiştir. En yüksek $R^{2}$ değeri, $\mathrm{PM}_{10}$ modelinde olduğu gibi, tüm bağımsız değişkenlerin modele dahil edildiği adım (4.adım) olan son modelde tespit edilmiştir. Model için hesaplanan $\mathrm{R}^{2}$ değeri 0.24 olup, bu değer $\mathrm{PM}_{10}$ modeli için hesaplanan $\mathrm{R}^{2}$ değerinden nispeten daha yüksektir. Dolayısıyla, model sonucuna göre, tüm meteorolojik parametreler dahil edilerek $\mathrm{SO}_{2}$ seviye tahminleri ancak \%24 oranında açıklanabilmektedir.

\subsection{Hava Kirleticilerine Ait Trend Analizleri}

Trend analizleri son yıllarda geniş veri setleri içeren klimatolojik ve hidrolojik uygulamalarda

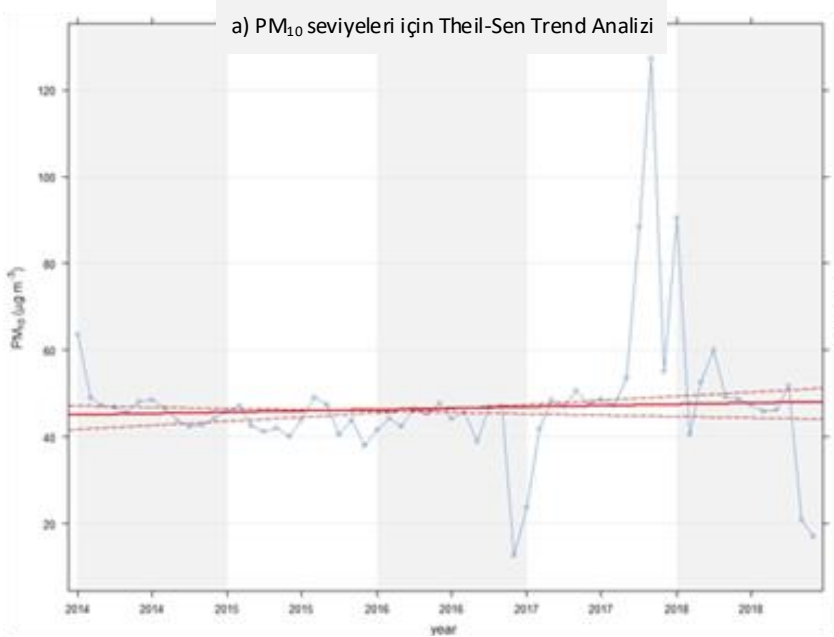

kullanılmaktadır (Guerreiro vd., 2014; Koudahe vd., 2017). Hava kirleticilerinin belirli bir bölge üzerinde zamanla değişimlerini incelemek için veri setlerinin doğasında var olan mevsimsellik değişimler, kayıp veriler veya anormal değerler içermesi nedeniyle parametrik olmayan istatistiksel yöntemlerle trend analizleri yapılmaktadır (Carslaw, 2015; Yolsal, 2016; Okello vd., 2018). Çevresel çalışmalara ait monotonik eğilimli trend analizleri için en az beş yıllık ve aylık bazda veri setlerinin kullanılması tavsiye edilirken, trendlerin doğrusal eğimleri yani birim zamandaki değişimlerinin çoklu yıllar zaman dilimi içinde belirlenmesi için Theil-Sen trend tahmini yöntemi kullanılmıştır (Carslaw, 2015). Sen trend analizi sonuçları $\mathrm{PM}_{10}$ ve $\mathrm{SO}_{2}$ değişimleri için Şekil 8'de sunulmuştur.

Şekil 8. (a) $\mathrm{PM}_{10}$ ve (b) $\mathrm{SO}_{2}$ seviyelerinin değişimlerine ait beş yıllık trend grafiğ

Theil-Sen trend analiz sonucunda, saatlik veriler üzerinde analiz edilmesini kolaylaştıran Carslaw Algoritması kullanılarak R ortamında elde edilen ve Şekil 8a'da sunulan grafiğe göre, kırmızı düz çizgiler son beş yıla ait $\mathrm{PM}_{10}$ tahmin ortalamalarını, kesikli kırmızı çizgiler ise tahmin değerlerine ait $\% 95$ seviyede güven aralıklarını ifade etmektedir. Theil-Sen trend analizine göre, son beş yıllık zaman dilimi içerisinde $\mathrm{PM}_{10}$ seviyeleri yıllık ortalama $45-50 \mu \mathrm{g} / \mathrm{m}^{3}$ aralı̆̆ında olacak şekilde artış eğilimi göstermektedir. Benzer şekilde, Theil-Sen trend analizi, çalışma alanında $\mathrm{SO}_{2}$ seviyelerinin değişimleri için uygulanmış olup, trend analizi sonuçları Şekil $8 \mathrm{~b}$ 'de sunulmuştur. Theil-Sen trend analizi sonucunda göre, $\mathrm{PM}_{10}$ trend artışına benzer şekilde, $\mathrm{SO}_{2}$ seviyelerinin artış eğiliminde olduğu tespit edilmiştir. Söz konusu artış eğilimine göre,

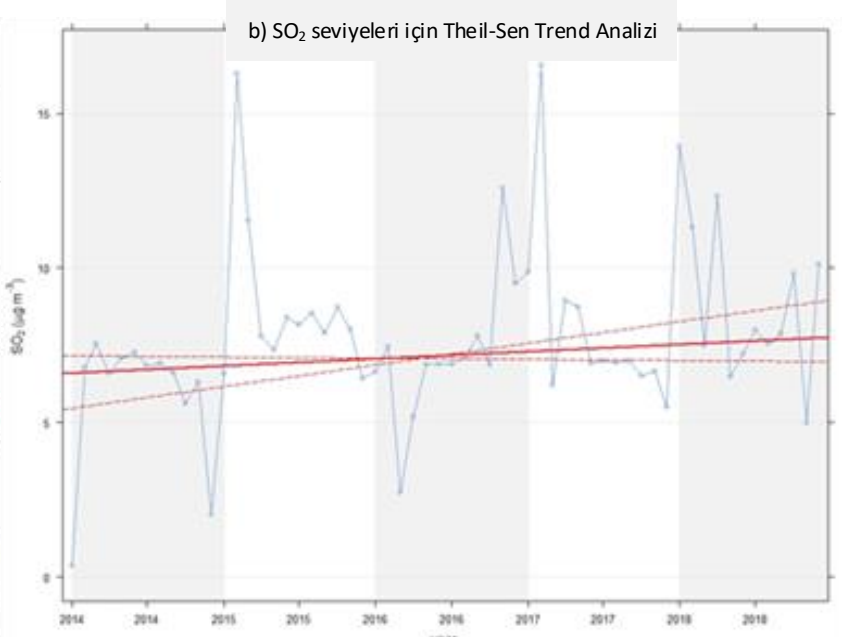

$\mathrm{SO}_{2}$ seviyesi ortalama $8 \mu \mathrm{g} / \mathrm{m}^{3}$ üzerinde olduğu analiz sonuçlarına göre ifade edilebilir.

\section{6. Şehir Merkezinde Hava Kirleticilerine Ait Epizotlar}

Şehir merkezinde son beş ylllık zaman dilimi içerisinde en yüksek $\mathrm{PM}_{10}$ konsantrasyonu 576.3 $\mu \mathrm{g} / \mathrm{m}^{3}$ olarak 1. Şubat.2015 günü ölçülmüştür. En yüksek $\mathrm{PM}_{10}$ seviyesinin ölçüldüğü y1l olan 2015 yılı için Carslaw Algoritması kullanılarak R ortamında oluşturulan kirlilik takviminde (Şekil 9) o y1la ait her bir takvim günü için ölçülen $\mathrm{PM}_{10}$ seviyeleri belirtilmiş ve bu şekilde yıl içi günlük $\mathrm{PM}_{10}$ dağılımları ve olası epizot günleri belirlenmesi için daha faydalı bir görsel oluşturulmuştur. Kirlilik takviminden de görüleceği üzere en yüksek $\mathrm{PM}_{10}$ seviyesine sahip 
gün 1. Şubat günü olarak tespit edilmiş olup, epizot günü için bu tarih seçilmiştir. En yüksek $\mathrm{PM}_{10}$ konsantrasyonun ölçüldüğü günün öncesinde veya sonrasında herhangi bir yüksek değer oluşmadığı da kirlilik takviminden görülebilmektedir. Sadece 1. Şubat gününü özel yapan ve $\mathrm{PM}_{10}$ konsantrasyonun maksimum seviyeye çıkaran olağan dışı bir durumun incelenmesi gerekmektedir.

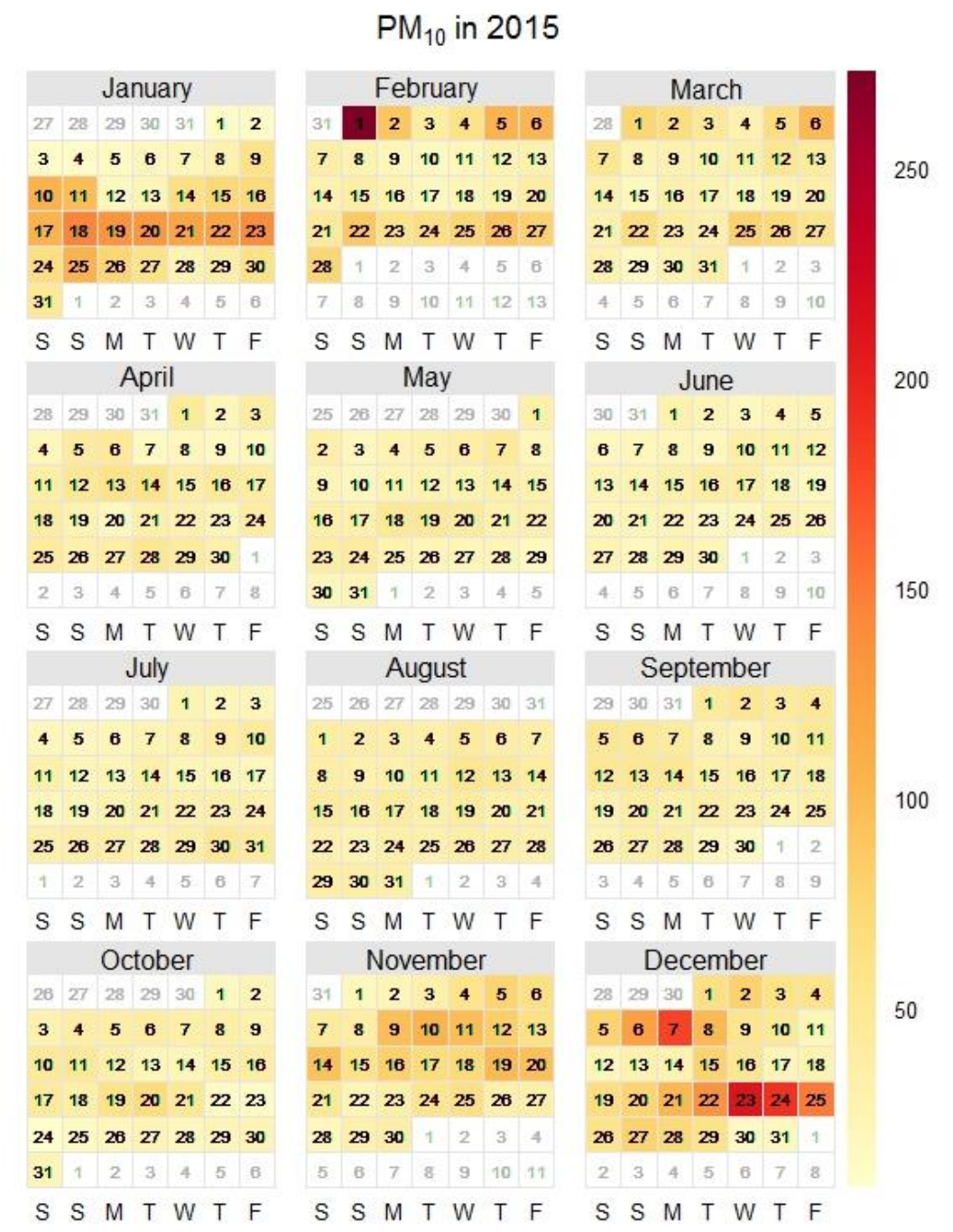

Şekil 9. 2015 y1lı için $\mathrm{PM}_{10}$ seviyeleri için oluşturulan kirlilik takvimi

Epizot gününe ait olağan dışı durumun incelenmesinde, şehir merkezinin olduğu bölgede olası çevreden gelen toz taşınımları önem kazanmaktadır ve zaman zaman etkili olmaktadır. Dış bölgelerden hatta diğer ülke veya kitalardan gelen toz yüklerinin araştırılmasında iki kaynak kullanılmıştır. $\mathrm{Bu}$ kaynaklardan ilki, Dünya Meteoroloji Örgütünün yönetiminde olan ve Barcelona Super Computing Center (BSCC) tarafindan geliştirilen Global Toz Tahmini verileri incelenmiştir (URL-2, 2019). Epizot günü olan, 1.Şubat.2015 günü için veri tabanlarından Balıkesir merkez olmak üzere olasın toz taşınımları incelenmiş ve söz konusu tarihte Doğu Avrupa ve Ortadoğu bölgesi için yapılan hem BSCC toz taşınımı modelinde Balıkesir ilinin de içinde bulunduğu bölgeye (Şekil 10.a'da kırmızı çizgili daire içinde gösterilmiştir) Kuzey Afrika'dan yoğun olarak çöl tozlarının taşındığı sonucuna varılmıştır. Sözkonusu taşınım, merkezi Amerika Birleşik Devletleri'nde bulunan National Oceanic and Atmospheric Administration (NOAA) tarafindan geliştirilen HYSPLIT hava taşınım modellerinde de tespit edilmiş olup ilgili model görseli Şekil 10.b'de sunulmuştur (URL-3, 2019). HYSPLIT modelinde ise yine Kuzey Afrika'dan başlayan ve Balıkesir ilin de içinde bulunduğu ülkenin batı kısımlarını etkileyen hava kütlesi hareketinin olduğu açıkça görülmektedir. Sonuç olarak, il merkezinde en yüksek $\mathrm{PM}_{10}$ konsantrasyonun ölçüldüğü epizot gününde Kuzey Afrika'dan kıtasal toz taşınımından gelen çöl tozlarının etkili olduğu sonucu çıkartılabilir. 


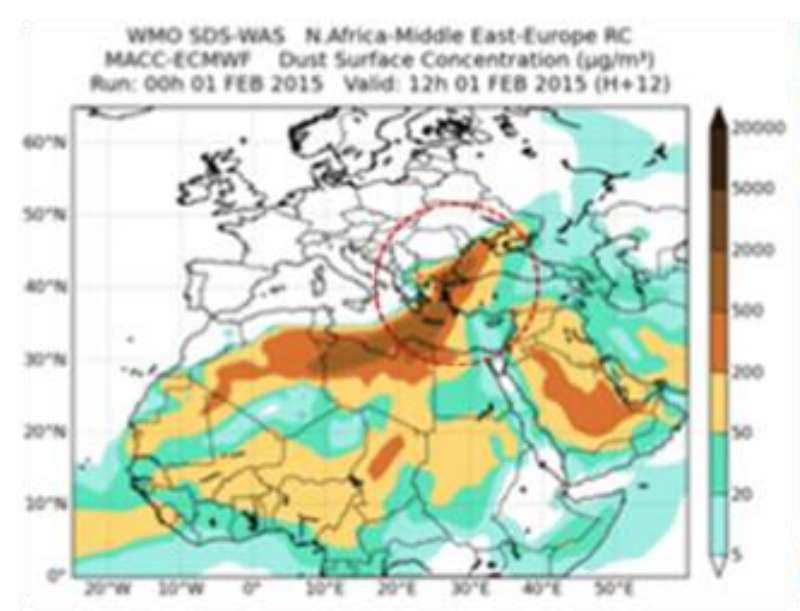

(a)

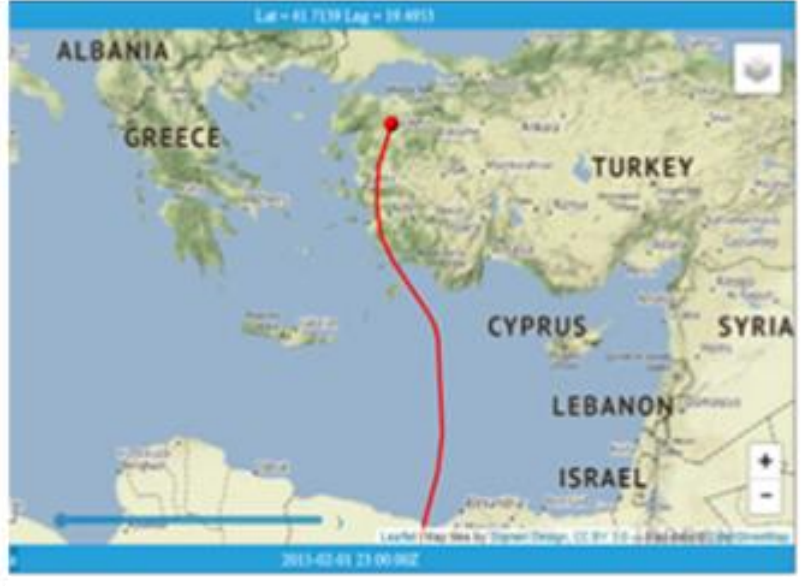

(b)

Şekil 10. (a) Barcelona Super Computing Center tarafından oluşturulan toz taşınım modeli, (b) NOOA HYSPLIT trajectory modeline göre hava kütlesi taşınım modeli

Yine aynı şekilde, şehir içinde ölçülen uzun yıllık $\mathrm{SO}_{2}$ konsantrasyonları içinde en yüksek $\mathrm{SO}_{2}$ konsantrasyonu $146.9 \mu \mathrm{g} / \mathrm{m}^{3}$ olarak 8.Aralık.2018 günü ölçülmüştür. Tipik olarak, daha önceki analizlerden de anlaşlabileceği üzere, Şekil 11.'de sunulan 2018 y1lına ait kirlilik takviminde de gösterildiği gibi, $\mathrm{SO}_{2}$ konsantrasyonları yılın ilk ayı ve son aylarındaki dönemi kapsayan kış mevsiminde en yüksek seviyelere ulaştığ 1 açıç̧a görülebilmektedir. İlgili kirlilik takviminde 8.Aralık ve kısmen de 9.Aralık günlerinde en yüksek $\mathrm{SO}_{2}$ seviyeleri ölçülmüş olup, epizot günü olarak 8. Aralık.2018 günü belirlenmiştir.
$\mathrm{SO}_{2}$ in 2018

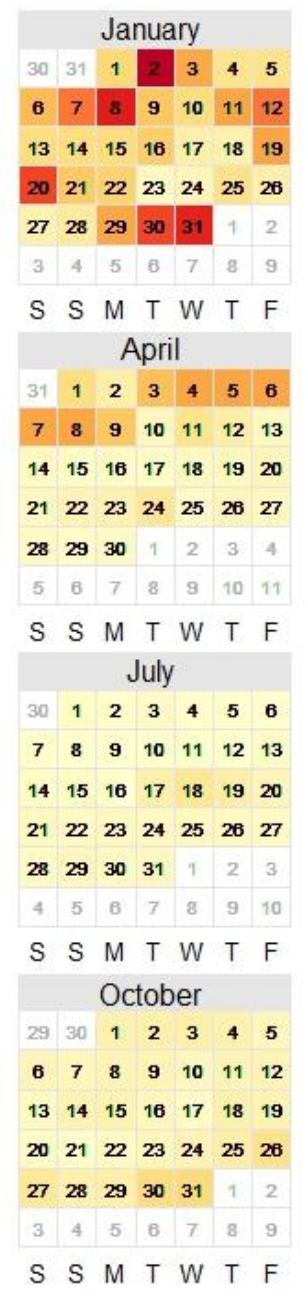

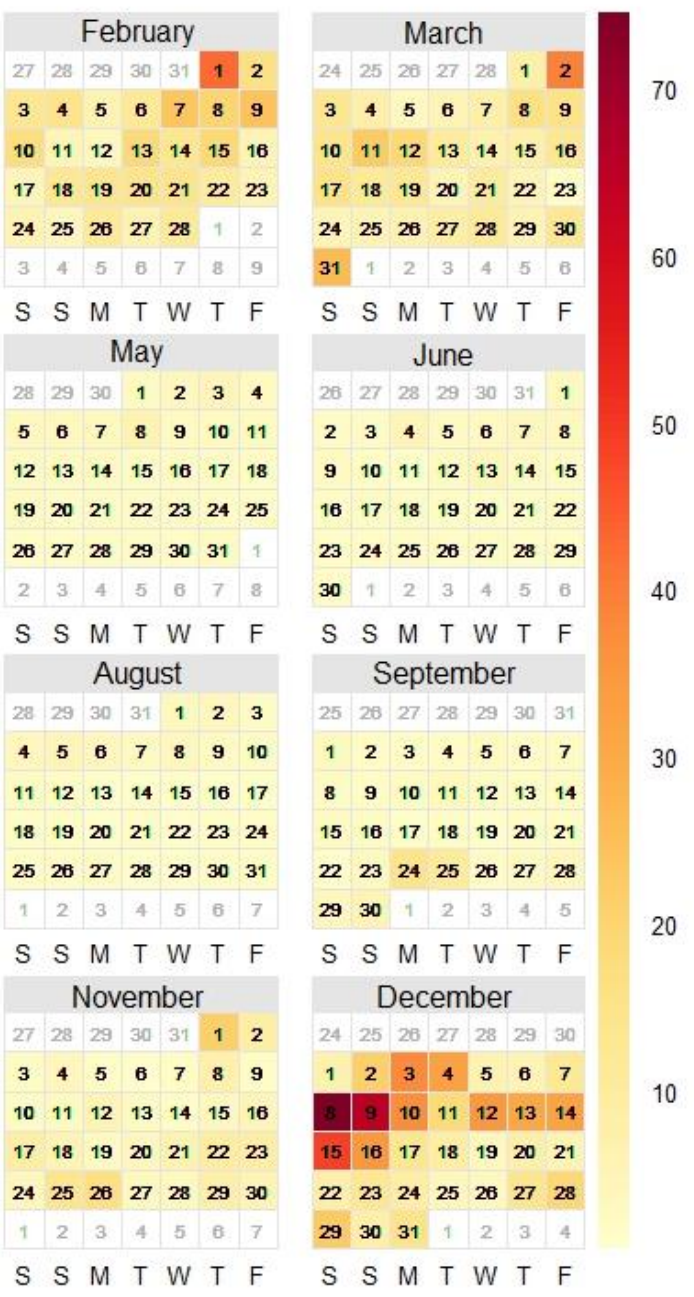

Şekil 11. 2018 yılı için $\mathrm{SO}_{2}$ seviyeleri için oluşturulan kirlilik takvimi 
Balıkesir şehir merkezinde son beş yıllık zaman diliminde diğer yıllarda maksimum seviye 60 $\mu \mathrm{g} / \mathrm{m}^{3}$ seviyesini geçmediği görülmektedir. Şehir merkezine ait $\mathrm{SO}_{2}$ epizot gününde bu anlık yükselişin sebebi iki yönlü düşünülebilir. İlk neden, o gün için oluşabilecek ani sıcaklık düşüşleridir. Epizot günü sıcaklık değeri $5{ }^{\circ} \mathrm{C}$ civarındadır. Dolayısıyla mevsim normalleri altında anormal bir soğuk hava etkisi olmamaktadır. Diğer neden ise, toz taşınımlarında olduğu gibi dış bölgelerden şehir merkezine doğru olabilecek hava kütlesi taşınımları olduğu düşünülmektedir.

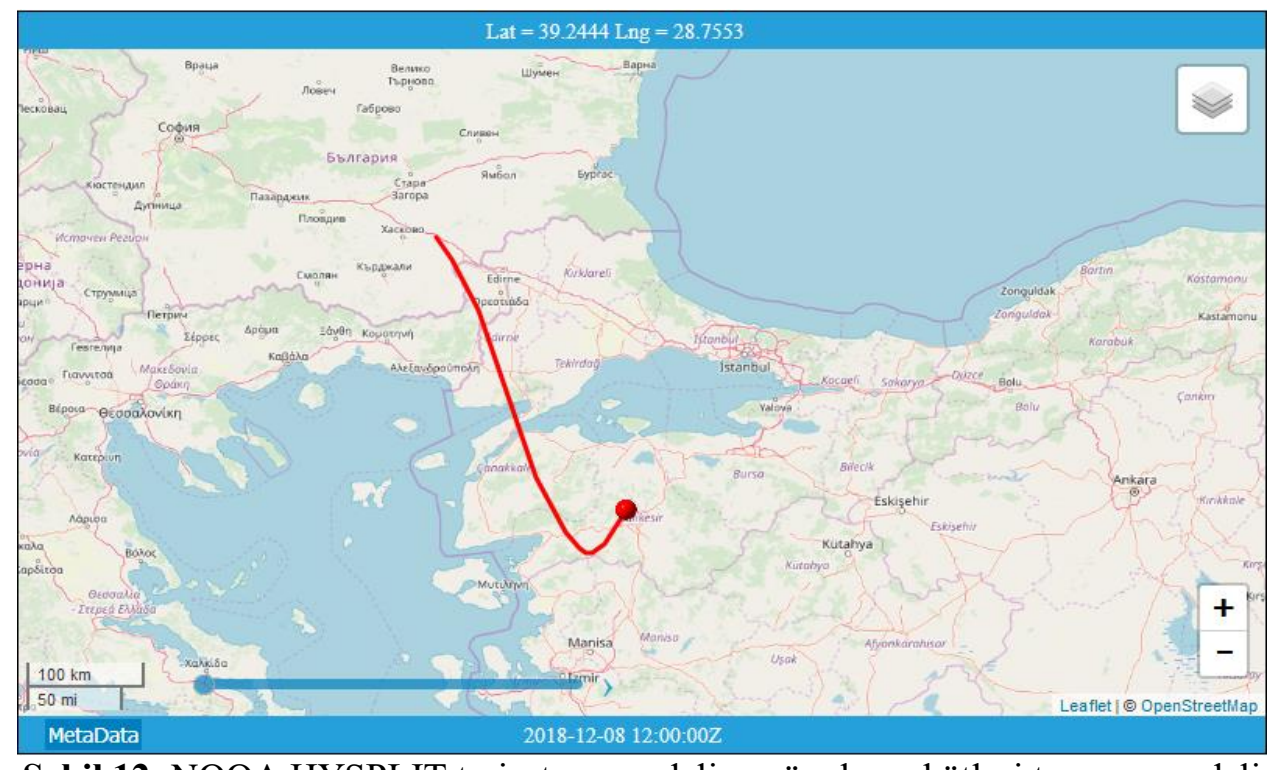

Şekil 12. NOOA HYSPLIT trajectory modeline göre hava kütlesi taşınım modeli

Balıkesir şehir merkezine, epizot günü olan 8.Aralık günü oluşan hava kütleleri taşınımları NOAA HYSPLIT algoritması kullanılarak analiz edildiğinde, Şekil 12.'de gösterildiği gibi hava kütlesi taşınımlarının o günlerde Bulgaristan'ın güney doğu bölgesi üzerinden geldiği ve Bulgaristan'ın ülkemize sınırına yakın olan güney doğu bölgesinde Kovachevo şehrinde bulunan ve enerji üretim kapasiteleri 200-300 MW arasinda değişen kömürle çalışan üç adet Maritsa Iztok santralleri, yine yakın bölgede Obruchiste şehrinde bulunan $50 \mathrm{MW}$ kapasiteli dört adet Brikel santrali ve Devin şehrinde bulunan 172 MW kapasiteli dört adet Deven santrali olmak üzere yaklaşık on bir adet termik santrallerden salınan $\mathrm{SO}_{2}$ gazının etkisinde olabileceği tahmin edilmektedir. Ayrıca diğer önemli bir husus ise, Balıkesir şehir merkezi için geçmiş yıllara ait uzun dönemlik meteorolojik veriler incelendiğinde, bölgeye ait tipik enverziyon (atmosferik sıcaklık tersellenmesi) oluşumları özellikle Aralık aylarında en şiddetli seviyelerde olduğu tespit edilmiştir. $\mathrm{SO}_{2}$ seviyesinin maksimum olduğu epizot günü incelemesinde lokal enverziyon etkisinin de olduğu düşünülmektedir ve ayrı bir çalışma kapsamında detaylı olarak incelenmesi gerekmektedir.

\section{Kaynaklar}

Alberini, A. ve Krupnick, A., 1998. Air Quality and Episodes of Acute Respiratory Illness in Taiwan Cities: Evidence from Survey Data. Journal of Urban Economics, 44 (1), 68-92.

Beaver, S. ve Palazoglu, A., 2009. Influence of synoptic and mesoscale meteorology on ozone pollution potential for San Joaquin Valley of California. Atmospheric Environment, 43, 1779-1788.

Borge, R., Lumbreras, J., Perez, J., de la Paz, D. ve Vedrenne, M., 2014. Emission inventories and modeling requirements for the development of air quality plans. Application to Madrid (Spain). Science of the Total Environment, 466, 809819.

Brunekreef, B. ve Holgate, S.T., 2002. Air pollution and health. The Lancet, 360 (9341), 1233-1242.

Carslaw, D.C. ve Ropkins, K., 2012. Openair - an R package for air quality data analysis. Environmental Modelling \& Software, 27 (28), 52-61.

Carslaw, D.C., 2015. The open-air manual - opensource tools for analyzing air pollution data. Manual for version 1.1-4, King's College London, UK. 287p. 
Cerro, J.C., Cerda, V. ve Pey, J., 2015. Trends of air pollution in the western Mediterranean Basin from a 13-year database: A research considering regional, suburban and urban environments in Mallorca (Balearic Islands). Atmospheric Environment, 103,138-146.

Csavina, J., Field, J., Félix, O., Corral-Avitia, A.Y., Sáez A.E. ve Betterton, E.A., 2014. Effect of wind speed and relative humidity on atmospheric dust concentrations in semi-arid climates. Science of the Total Environment, 487, 82-90.

Çakır, S. ve Abdullah, A.H., 2017. Hava kirletici konsantrasyonlarının meteorolojik parametrelere dayalı çoklu-lineer regresyonla analizi: Kuzey Kıbrıs Örneği, VII. Ulusal Hava Kirliliği ve Kontrolü Sempozyumu, 1-3 Kasım 2017, Antalya, s. 17.

Elbir, T., Müzezzinoğlu, A. ve Bayram, A., 2000. Evaluation of some air pollution indicators in Turkey. Environmental International, 26, 5-10.

Elminir, H.K., 2005. Dependence of urban air pollutants on meteorology. Science of the Total Environment, 350, 225-237.

Gomzi, M., 1999. Indoor air and respiratory health in preadolescent children. Atmospheric Environment, 33 (24-25), 4081-4086.

Guerreiro, C., Foltescu, V. ve De Leeuw, F., 2014. Air quality status and trends in Europe. Atmospheric Environment, 98, 376-384.

Helander, M.L., Savolainen, J. ve Ahlholm, J., 1997. Effects of air pollution and other environmental factors on birch pollen allergens. Allergy: European Journal of Allergy \& Clinical Immunology, 52(12), 1207-1214.

HKDYY, 2008. Hava Kalitesi Değerlendirme ve Yönetimi Yönetmeliği, Resmi Gazete Tarihi: 06.06.2008, Resmi Gazete Sayıs1: 26898. Ankara.

Jacob, D.J. ve Winner, D.A., 2009. Effect of climate change on air quality. Atmospheric Environment, 43, 51-63.

Koçman, A., 1993. Türkiye İklimi, Ege Üniversitesi Yayınları, Yayın No:72, İzmir.

Koudahe, K., Djaman, K., Bodian, A., Irmak, S., Sall, M., Diop, L., Balde, A.B. ve Rudnick, D., 2017. Trend analysis in rainfall, reference evapotranspiration and aridity index in southern senegal: adaptation to the vulnerability of rainfed rice cultivation to climate change. Atmospheric and Climate Sciences, 7 (4), 476495.
Martonen T.B. ve Schroeter, J.D., 2003. Risk assessment dosimetry model for inhaled particulate matter: I. Human subjects. Toxicology Letters, 138 (1-2), 119-132.

Monn, C., Alean-Kirkpatrick, P., Künzli, N., Defila, C., Peeters, A., Ackermann-Liebrich, U., Leuenberger, F. ve SAPALDIA Team, 1999. Air pollution, climate and pollen comparisons in urban, rural and alpine regions in Switzerland (SAPALDIA study). Atmospheric Environment, 33 (15), 2411-2416.

Moshammer, H. ve Neuberger, M., 2003. The active surface of suspended particles as a predictor of lung function and pulmonary symptoms in Austrian school children. Atmospheric Environment, 37, 1737-1744.

Mutlu, A., 2018. Sanayi kaynaklı karbonmonoksit salınımlarının AERMOD dağılım modeli ile incelenmesi. Uludağ Üniversitesi Mühendislik Fakültesi Dergisi, 23(2), 275-286. Doi: 10.17482/uumfd.398123.

Mutlu, A., 2019. Balıkesir şehir merkezinde trafik kaynaklı hava kirliliği seviyelerinin analizi, BAUN Fen Bil. Enst. Dergisi, 21 (1), 152-168. Doi: 10.25092/baunfbed.532605.

Okello, N.O., Camminga, S., Okello, T.W. ve Zunckel, Mark., 2018. Spatial and temporal trends of $\mathrm{PM}_{10}$ and $\mathrm{SO}_{2}$ in the Richards Bay area. Clean Air Journal, 28 (2), 80-89.

Radaideh, J.A., 2017. Effect of meteorological variables on air pollutants variation in arid climates. Journal of Environmental \& Analytical Toxicology, 7 (4), 1-12.

Samoli, E., Stafoggia, M., Rodopoulou, S., Ostro, B., Declercq, C., Alessandrini, E., Díaz, J., Karanasiou, A., Kelessis, A., Le Tertre, A., Pandolfi, P., Randi, G., Scarinzi, C., ZauliSajani, S., Katsouyanni, K. ve Forastiere, F., 2013. Associations between fine and coarse particles and mortality in Mediterranean cities: results from the MED-particles project. Environ. Health Perspect., 121, 8.

Sanchez de la Campa, A.M., Sánchez-Rodas, D., Alsioufi, L., Alastuey, A., Querol, X., ve de la Rosa, J.D., 2018. Air quality trends in an industrialised area of SW Spain. Journal of Cleaner Production, 186, 465-474.

Stafoggia, M., Samoli, E., Alessandrini, E., Cadum, E., Ostro, B., Berti, G., Faustini, A., Jacquemin, Linares C., Pascal, M., Randi, G., Ranzi, A., Stivanello, E. ve Forastiere, F., 2013. Shortterm associations between fine and coarse particulate matter and hospitalizations in southern Europe: Results from the MED- 
particles project. Environ. Health Perspect., 121, 9.

Tağıl, Ş., 2007. Balıkesir'de hava kirliliğinin solunum yolu hastalıklarının mekânsal dağılışı üzerine etkisini anlamada jeo-istatistik teknikler, Coğrafi Bilimler Dergisi, 5 (1), 37-56.

Tecer, L.H., 2009. A factor analysis study: Air pollution, meteorology, and hospital admissions for respiratory diseases. Toxicological \& Environmental Chemistry. 91 (7), 1399-1411.

Tecer, L.H., 2013. Balıkesir'de hava kirliliğinin çocuk ve yetişkinlerde solunum hastalıklarına etkilerinin belirlenmesi üzerine bir alan çalışması. Hava Kirliliği Araştırmaları Dergisi, 2, 11-20.

Tian, J. ve Fernandez, G., 1999. Seasonal trend analysis of monthly water quality data. University of Alberta School of Business Research Paper No. 2013-1203. URL https://ssrn.com/abstract=2284439. 02 Nisan 2019.

Timonen, K.L., Pekkanen, J., Tiittanen, P. ve Salonen, R.O., 2002. Effects of air pollution on changes in lung function induced by exercise in children with chronic respiratory sypmtoms. Occup. Environ. Med., 59, 129-134.

Topal, M.H. ve Hayaloğlu, P., 2017. Farklı Gelişmişlik Düzeylerinde Kurumsal Kalitenin Çevre Performansı Üzerindeki Etkisi: Ampirik Bir Analiz. Sosyoekonomi, 25 (32), 189-212.

URL-1, 2017. TÜİK, Yıllara göe bölge nüfusları. 20002017.

URL-1, http://www.tuik.gov.tr/UstMenu.do?metod=tem elist. 18 Şubat 2019.

URL-2, 2019. Barcelona Super Computing Center, Global toz dağılımı merkezi. Https://sdswas.aemet.es/forecast-products/dust-forecasts. URL, https://sds-was.aemet.es/forecastproducts/dust-forecasts. 08 Nisan 2019.

URL-3, 2019, National Oceanic and Atmospheric Administration (NOAA), HYSPLIT taşınım modellemesi.

Https://www.ready.noaa.gov/HYSPLIT_traj.ph p.
URL, https://www.ready.noaa.gov/READYtransp.php. 02 Nisan 2019.

Visscher, A., 2014. Air Dispersion Modeling, John Wiley \& Sons Press. Hoboken, New Jersey. $634 \mathrm{p}$.

Wang, L.K., Pereria, N.C. ve Hung, Y.T., 2004. Air Pollution Control Engineering, Humana Press, Totowa, New Jersey. 505 p.

WHO (World Health Organization), 2006. Air quality guidelines for particulate matter, ozone, nitrogen dioxide and sulfur dioxide. Summary of Risk Assessment. Geneva, Switzerland.

WHO (World Health Organization), 2016. Ambient Air Pollution: A Global Assessment of exposure and burden of disease. Geneva, Switzerland.

Williams, R., Creason, J., Zweidinger, R., Watts, R., Sheldon L. ve Shy, C., 2000. Indoor, outdoor, and personal exposure monitoring of particulate air pollution: the Baltimore elderly epidemiology-exposure pilot study. Atmospheric Environment, 34 (24), 4193-4204.

Wong, G. W. K., Ko, F. W. S., Lau, T. S., Li, S. T., Hui, D., Pang, S. W., Leung, R., Fok, T. F. ve Lai, C.K.W., 2000. Temporal relationship between air pollution and hospital admissions for asthmatic children in Hong Kong. Clinical and Experimental Allergy, 31 (4), 565-569.

Wordley, J., Walters, S. ve Ayres, J., 1997. Short term variations in hospital admissions and mortality and particulate air pollution. Occupational \& Environmental Medicine, 54(2), 108-116.

Y1lmaz, A., 2017. The effects of climate parametres on air pollution parametres: bolu province sample. Journal of Current Researches on Social Sciences, 7, 413-436.

Yolsal, H., 2016. Estimation of the air quality trends in Istanbul. Marmara Üniversitesi İktisadi ve İdari Bilimler Dergisi, 38(1), 375-399.

Zhang H., Wang Y., Hu J., Ying Q., ve Hu X.M., 2015. Relationships between meteorological parameters and criteria air pollutants in three megacities in China. Environmental Research, 140, 242-254. 